\title{
قراءة في كتاب \\ تاريخ الفلسفة في الإسلام \\ تأليف: دي بور
}

زكي الميلاد

من المؤلفات التي يعرفها الكتّاب والباحثون في حقل الفلسفة الإسلامية وتاريخها،

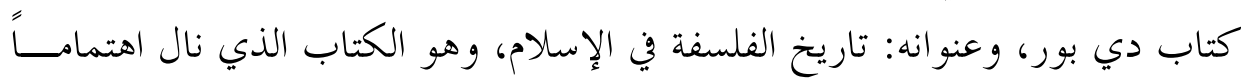

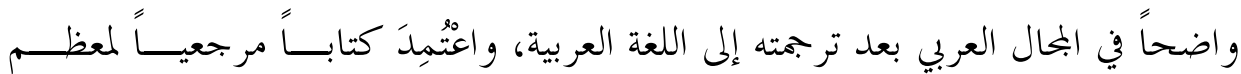

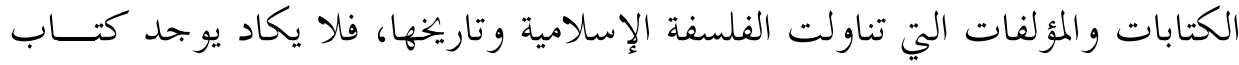

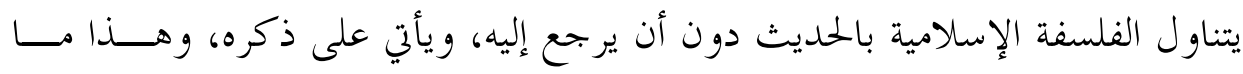
كشفته الكتابات و المؤلفات العديدة التي رجعت إليها.

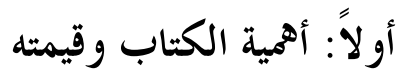

اكتسب الكتاب أهمية بالغة في بحال الكتابة والتــأليف في الفلســفة الإســلامية وتاريخها، نظراً إلى عاملين متعاضدين، هما:

1. كونه أول كتاب صدر مع مطلع القرن العشرين؛ إذ صدر باللغة الألمانية سنة

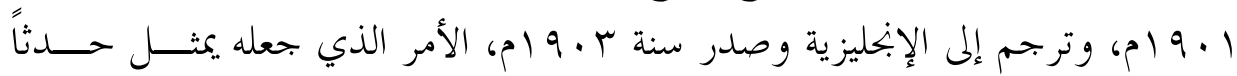

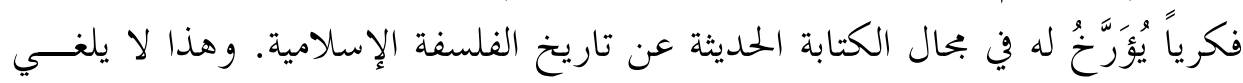

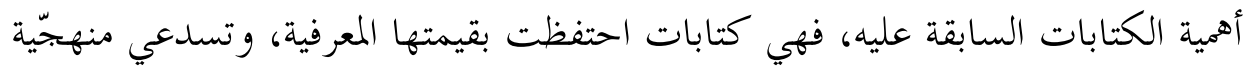
البحث، الحاجة إليها، والعودة الدائمة والمستمرة لها.

r. كون هذا الكتاب أول كتاب موسوعيّ في تاريخ الفلسفة الإسلامية؛، إذ تتبع

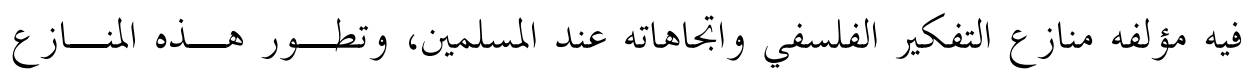

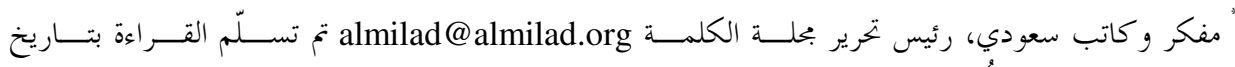

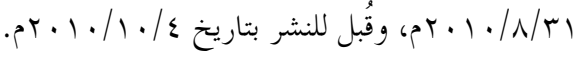




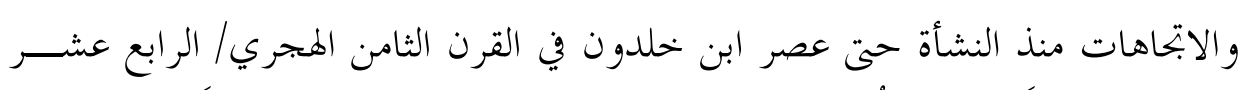

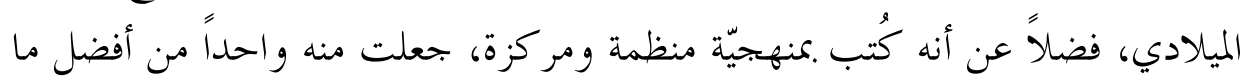

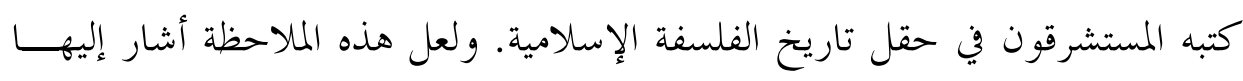

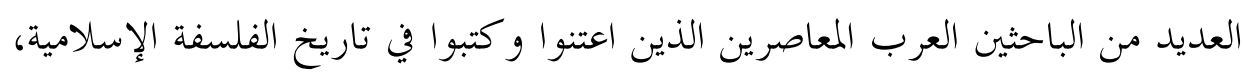

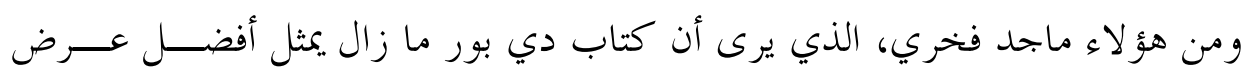

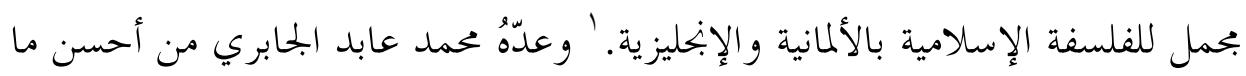

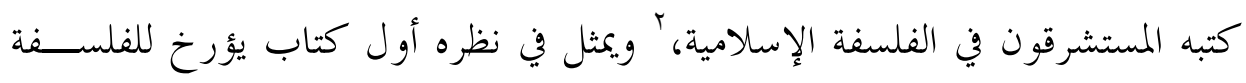

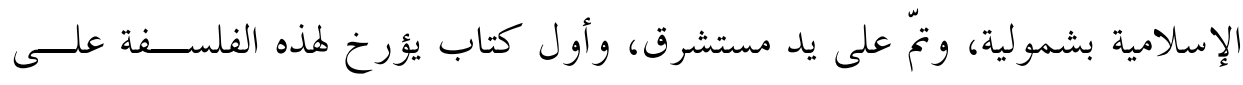
الطريقة الحمديثة.

وقد اتسعت شهرة هذا الكتاب، حتى أصبح نموذجاً يحتذيه الكتّــاب والبــاحثون

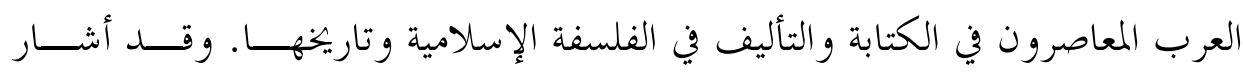

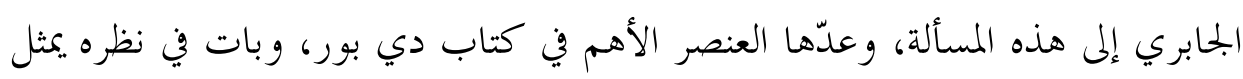

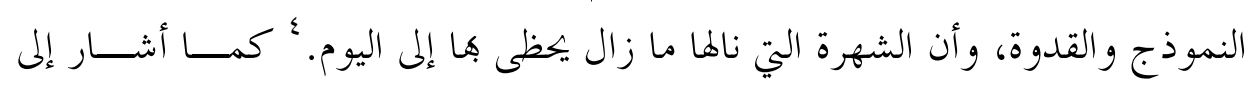

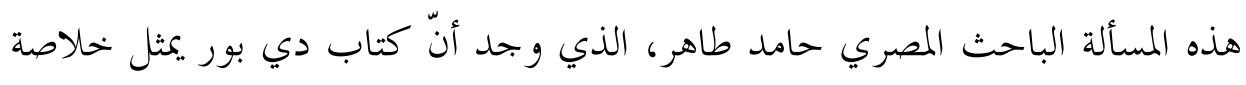

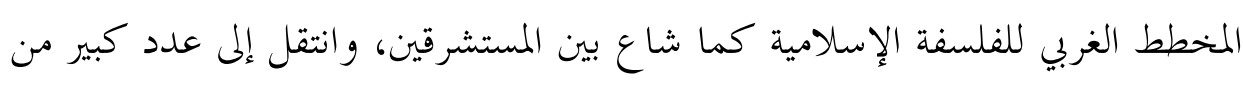

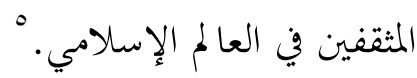

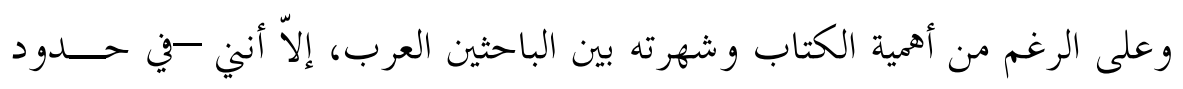

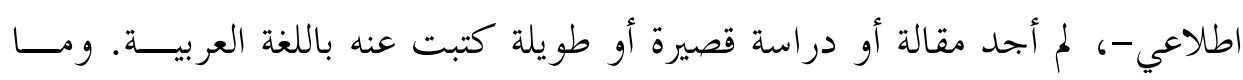
'فخري، ماجد. تاريخ الفلسفة الإسلامية منذ القرن الثامن حتى يومنا هذا، ترجمة: كمال اليازجي، بيروت: دار

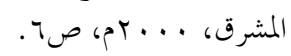

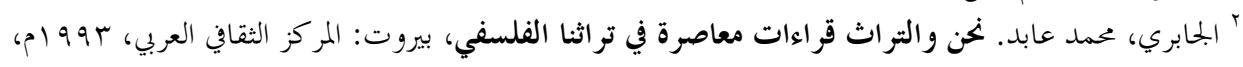

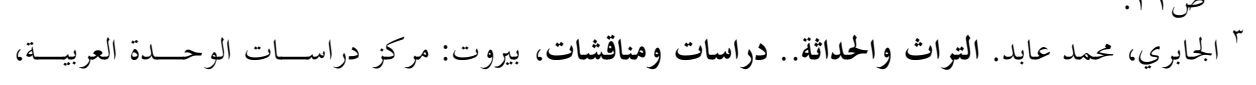

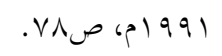

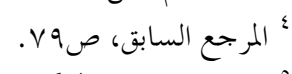
" بحموعة كتاب. الدكتور محمد عبد الهادي أبو ريدة كتاب تذكاري، الكويت: جامعسة الكويست، بو9 (1م) ص 


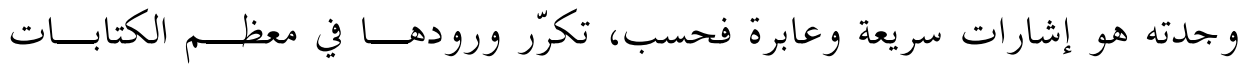

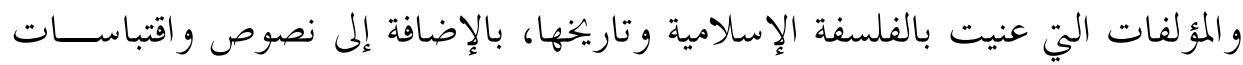

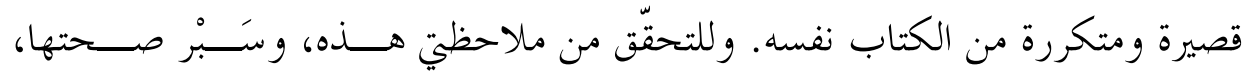

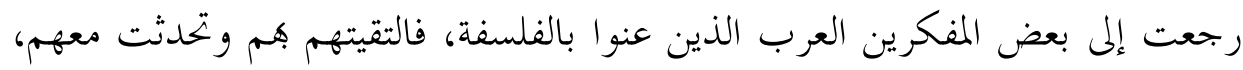

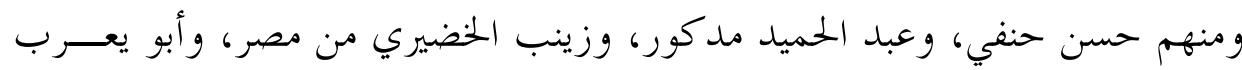

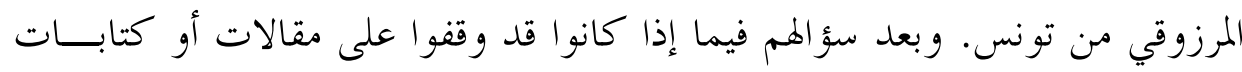

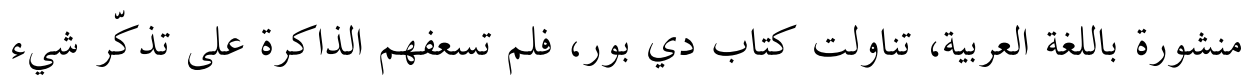
من هذا القبيل.

\section{ثانياً: المترجم و الترجمة}

قام محمد عبد الهادي أبو ريدة بترجمة كتاب دي بور إلى اللغة العربية، وصــدرت

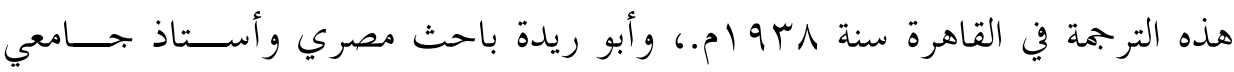
متخصص في حقل الفلسفة الإسلامية، وهو الحقل الذي ارتبطت به ســيرته العلميــة و الفكرية من المرحلة الجامعية، وبداية التخصص إلى فاية مشواره.

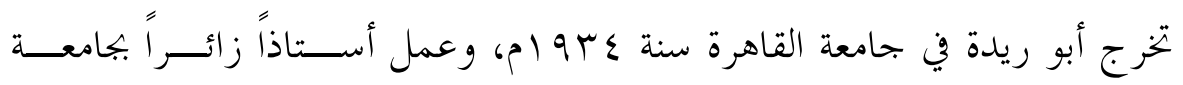

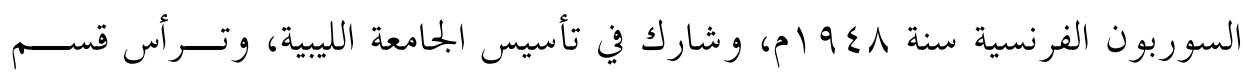

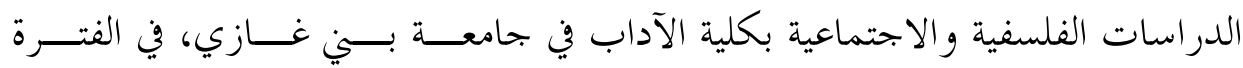

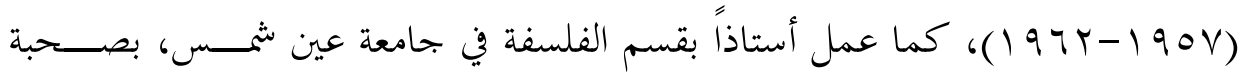

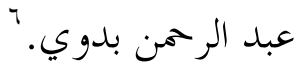

و انتدب ثانية لإنشاء قسم الفلسفة بجامعة الكويت، وترأس هذا القسم فترة مــن

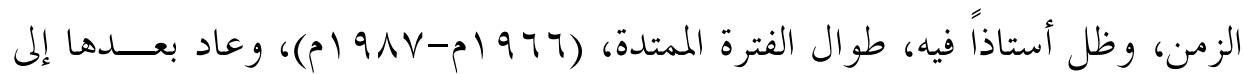
مصر ليشارك في أعمال الجمعية الفلسفية المصرية.

" أبو ريدة، محمد عبد الهادي. إبراهيم بن سيار النظام و آراؤه الكلامية والفلسفية، القاهرة: الهيئة المصرية العامة

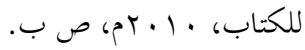


و شغل أبو ريدة، منصب مستشار ثقافي لمصر في مدريد سنة 9 \و ام بتز كية من طه حسين، و كلف بإنشاء المعهد المصري للدراسات الإسلامية في مدريد، و وكان أول ملئل

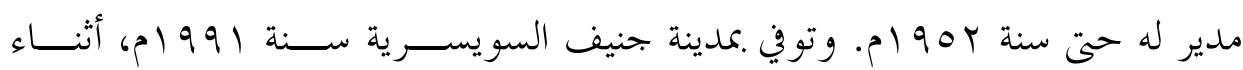

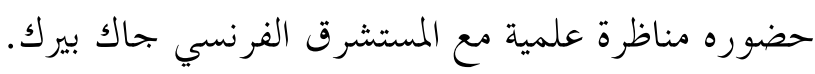
و تنحصر الأعمال الفكرية لأبي ريدة، في ثلاثة بحالات، هي: التأليف، و التحقيق،

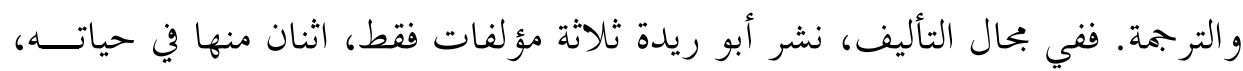
و الثالث نُشَرَ بعد وفاته من دون معرفة مسبقة منه، وهذه المؤلفات هي:

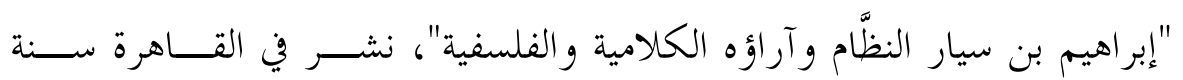

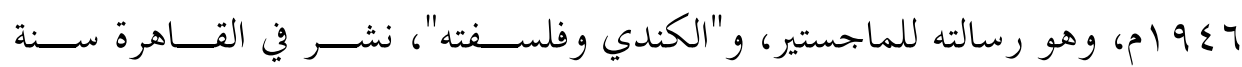
• 90 ام، وهو -في الأصل - المقدمة التي كتبها عند تحقيقه لرسائل الكندي الفلسفية.

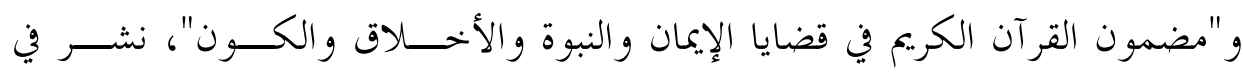

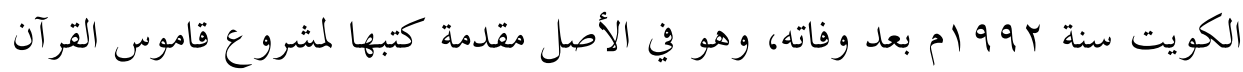
الكريم. أما رسالته التي تقدّم هـا لنيل الدكتوراه: "الغزالي و نقده للفلسفة اليونانية"، فقد وهد كتبها باللغة الألمانية، و لم تترجم إلى اللغة العربية حتى هذه اللحظة. ويظهر أن أبا ريدة كان مقّلّا في التأليف، ويفسر فؤاد زكريا هذا الأمر بقوله: "لم

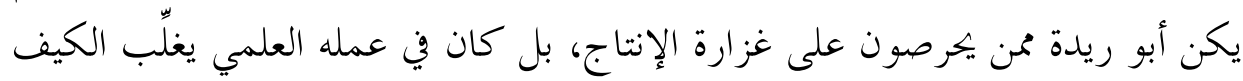

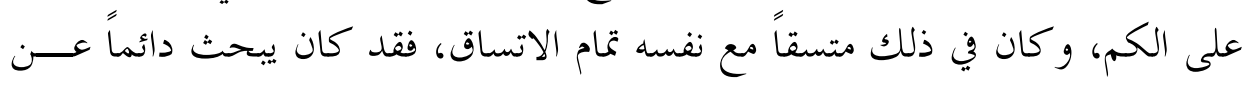
النوعية في الحياة، ويعرف كيف يتذوقها ويُرضى هـا حسّه المرهف. ولعل السبب الأهم

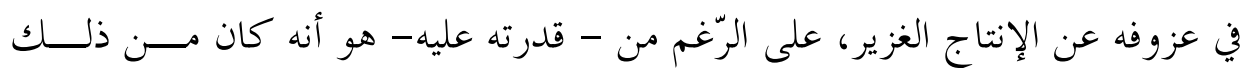

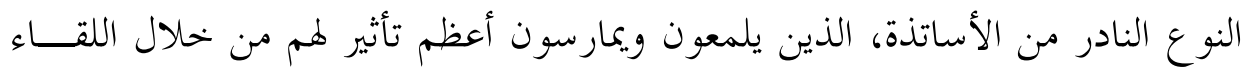

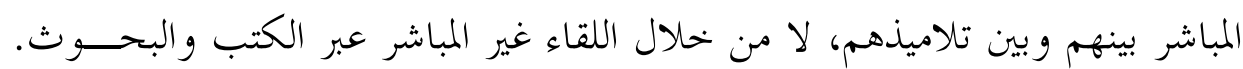

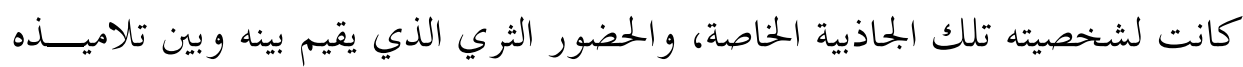

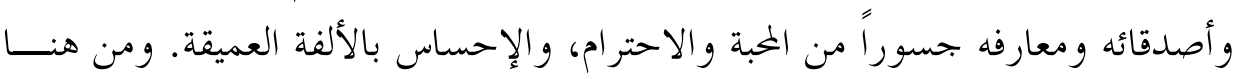

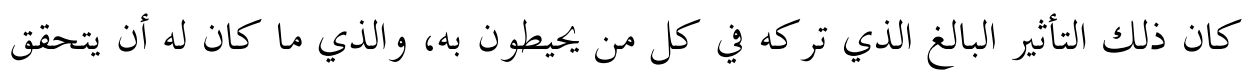




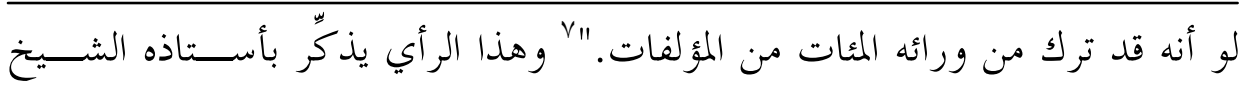
مصطفى عبد الرازق، ويجعله شديد الشبه به، في الإقلال من التأليف.

و في بحال التحقيق نشر أبو ريدة خمسة أعمال، ما زالت نصوصها مقروءة ولا غنى

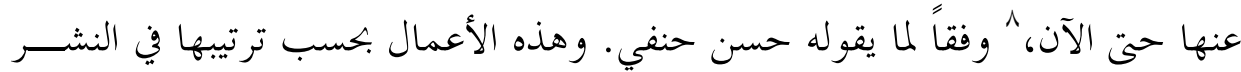
هي

"التمهيد في الرد على الملحدة و المعطِّة و الر افضة والحخوارج و المعتزلة"، لمؤلفـــهـ أبي

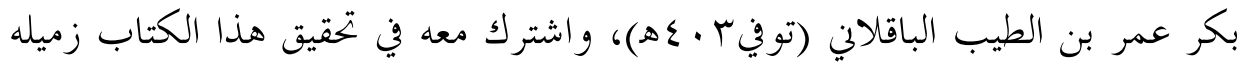

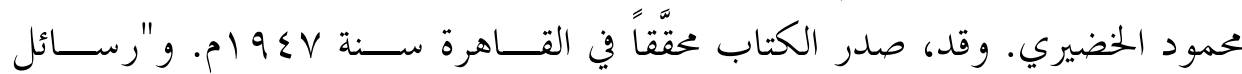
الكندي الفلسفية والطبيعية"، ويُعدّ هذا العمل في نظر بعض وفئ المفكرين في من أهم ما أنجزه

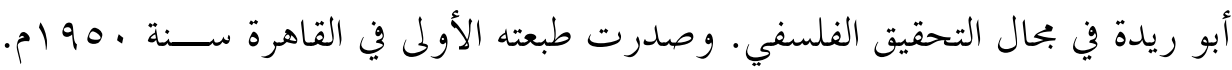

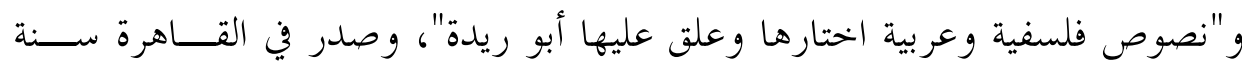

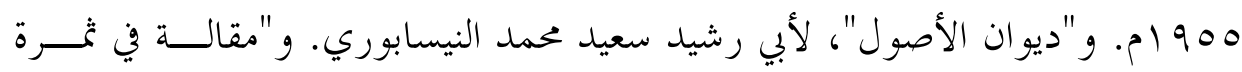

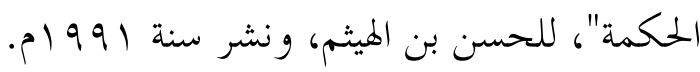

وفي بحال الترجمة نشر أبو ريدة خمسة أعمال. ويرى الدكتور أحمد عبد الحلـــيم

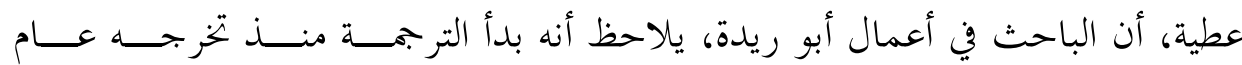

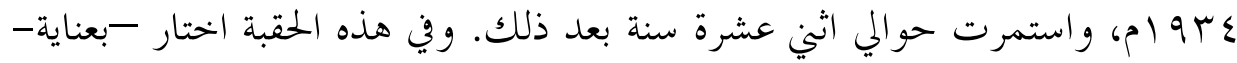

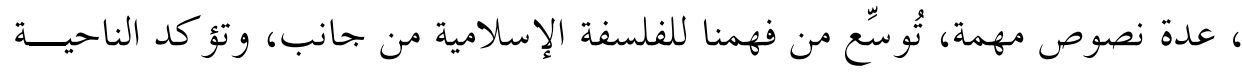

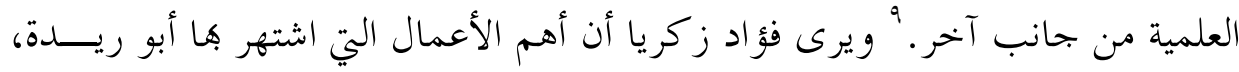

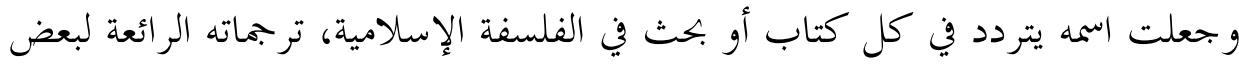
أعمال كبار المستشرقين.

وعرف عن أبو ريدة أنه كان يتقن العديد من اللغات الأجنبية، منـــها الألمانيـــة و الإبحليزية والفرنسية والإسبانية والفارسية، و بعض اللغات القديمة كاللاتينية و اليونانية. لمجموعة كتاب. الدكتور محمد عبد الهادي أبو ريدة كتاب تذكاري، مرجع سابق، ص9 1.

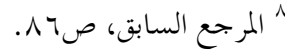

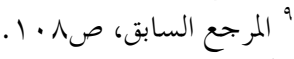
' المرجع السابق، صانق، صنا. 
ولا شكّ في أن إتقان هذه اللغات أعطى ترجمات "أبو ريدة" درجة عالية من الإتقـــان و الموثوقية والتميز، و كانت أغلب ترجماته عن اللغة الألمانية، التي كان له ولع كبير بها،

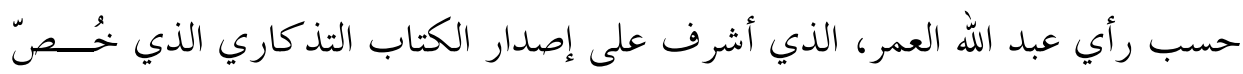

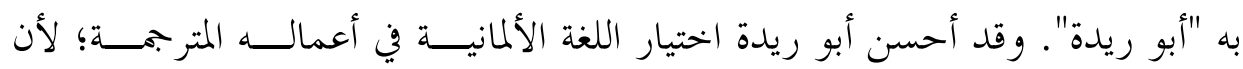

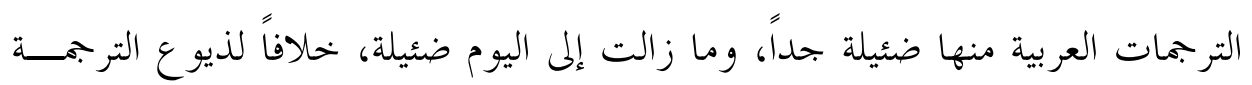
عن الإبحليزية و الفرنسية.

و المؤلفات التي ترجمها أبو ريدة بحسب ترتيبها الزمين في النشر بعد الترجمة، هي:

- "وجهة الإسلام.. نظرة في الحركات الحديثة في العالم الإسلامي"، وهو كتاب

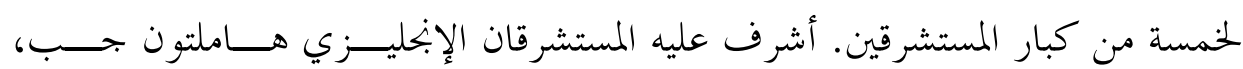

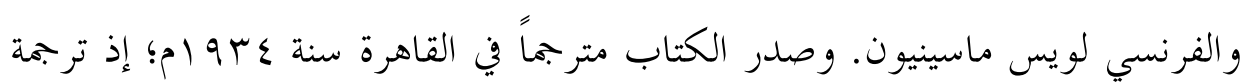

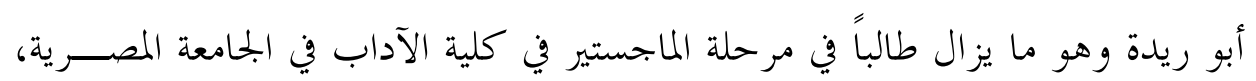

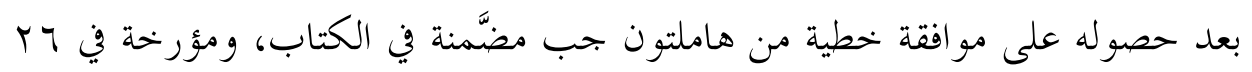
أبريل سبو ام.

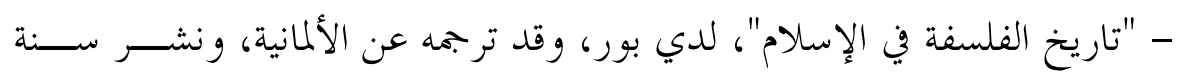
. $19 \mu \wedge$ - "الحضارة الإسلامية في القرن الرابع الهجري أو عصر النهضـــة في الإســلام"، للمستشرق الألماني آدم متز، نشر في جزأين سنة ، عو ام مترجماً عن اللغة الألمانيــة،

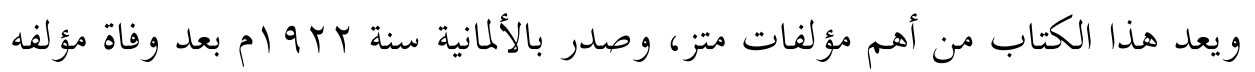

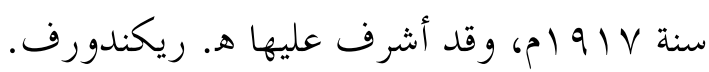

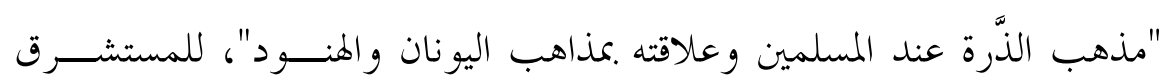

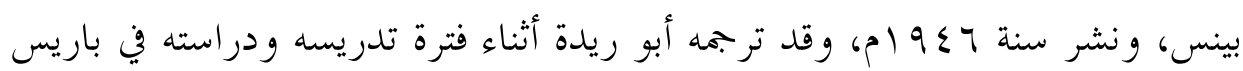

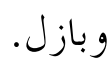




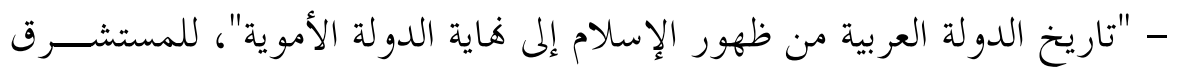

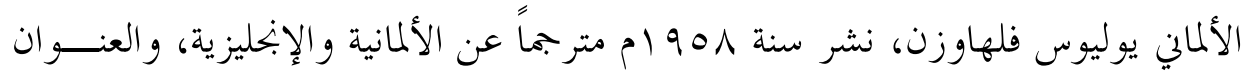

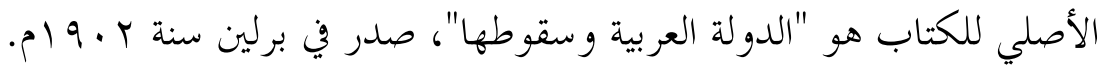

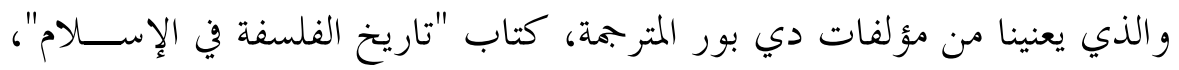

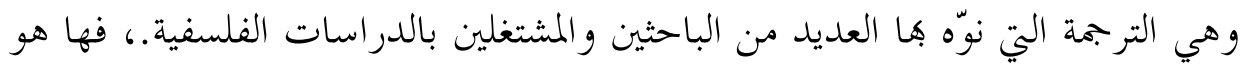

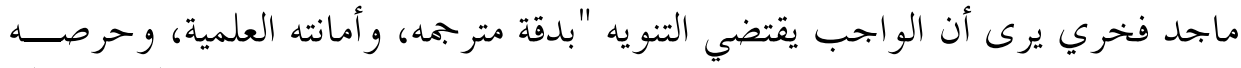

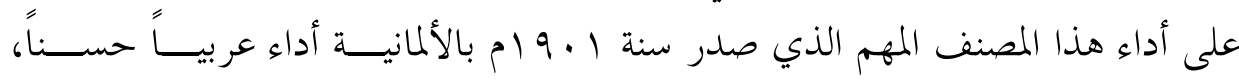

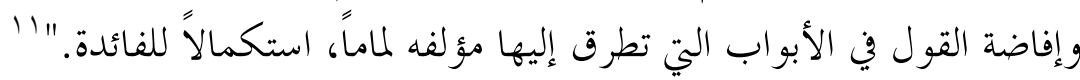

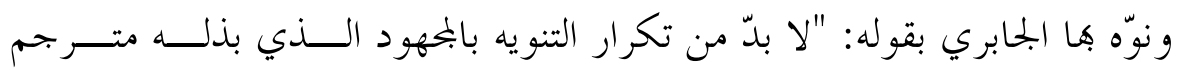

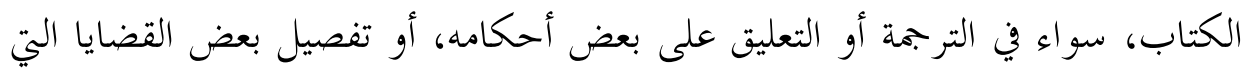

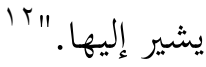

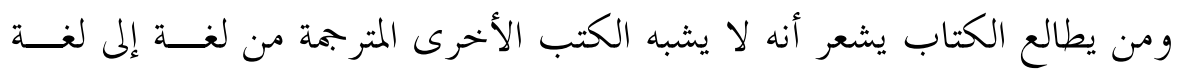

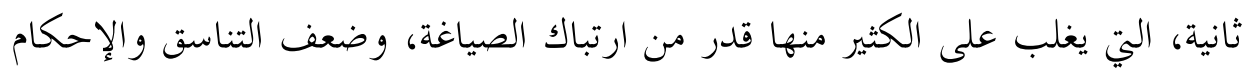

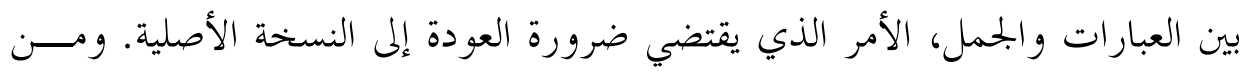

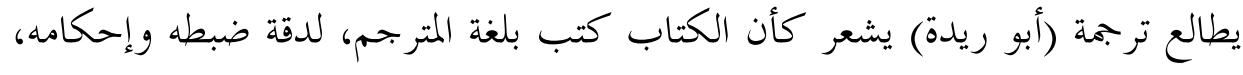

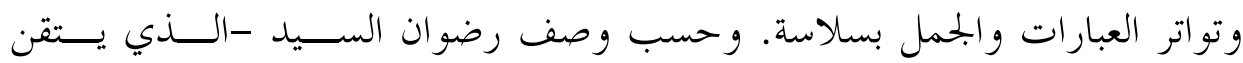

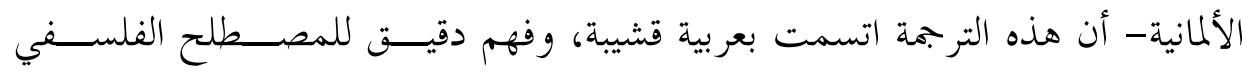
الألماني. آلمانة آن

ولو لا هذه الترجمة لما عرف دي بور في البحال العربي، ولما نال كتابه هذه الشهرة

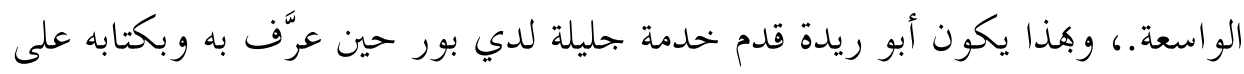

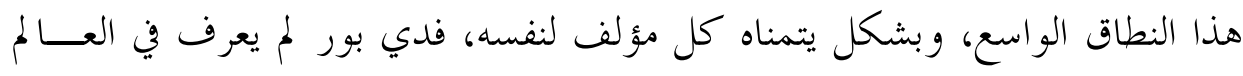

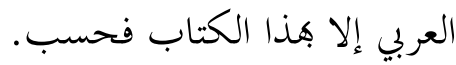

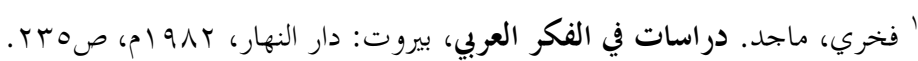

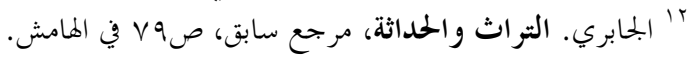

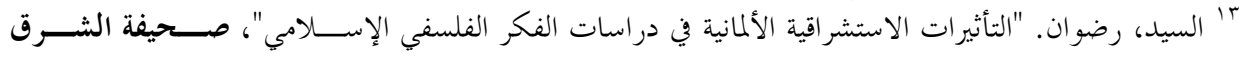

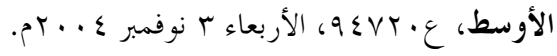


ثالثاً: تاريخ الفلسفة الإسلامية

في ثلاثينيات القرن العشرين التفت الباحثون المصريون المهتمون بحقل الدراســات

الفلسفية إلى نقص الكتابة في تاريخ الفلسفة الإسلامية، ووجود حاجة فعلية لكتابــات

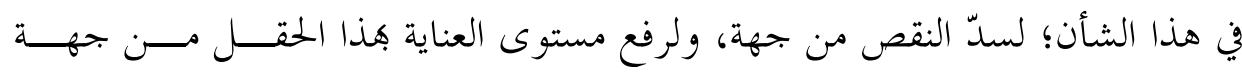
أخرى.

و كان في تقدير هؤلاء الباحثين، أن الغربيين لهم كتابات في هذا البحــال ينبغــي الوصول إليها، والتعرف عليها، بقصد تكوين المعرفة هما، والكشف عن طبيعة منــاهج الغربيين وخبرهم، والإحاطة بأفكارهم ونظرياقهم في دراسة تاريخ الفلسفة الإسلامية. ومن هنا جاءت عناية أبو ريدة هذا الكتاب. و كشف عن ذلك في مقدمة الطبعة الأولى المترجمة منه؛ إذ شرح رؤيته وغايته، التي يمكن تحديدها في ثلاثة عناصر أساسية هي:

ا ـ إن تاريخ الفلسفة يعدّ من أهم الدراسات التي فضت نحو الكمال في أوروبـــــا

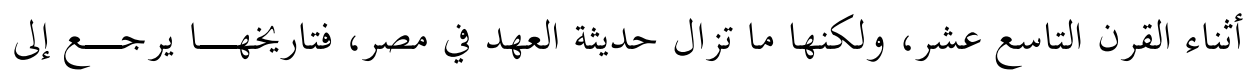
إنشاء الجامعة المصرية.

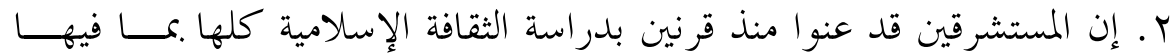

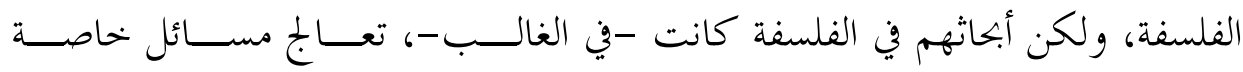
ومحدودة، وقلَّ أن توجد في بحوث المستشرقين كتب تحيط بتاريخ الفلسفة الإسلامية في جملتها، يستثنى منها كتاب دي بور، إلى جانب كتابين آخرين هما: كتاب المستشــرق الفرنسي "مِنْك" الذي يحمل عنوان: "أمشاج في الفلسفة اليهودية و العربية" الصادر في

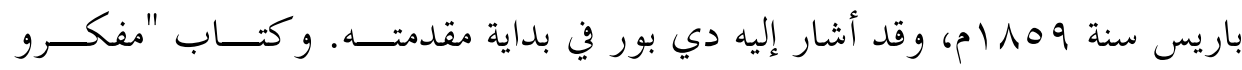
الإسلام" للمستشرق الفرنسي"بارون كر ادفو" الصادر بالفرنسية بعد سنة . ب 9 ام. 
r. لا يعرف في لغة العرب كتاب ظهر في تاريخ الفلسفة الإسلامية جدير بوصفه

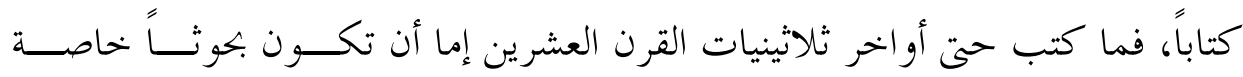

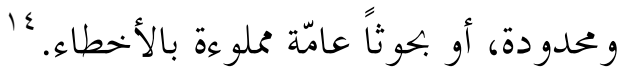

و يذكر أبو ريدة أن بعض أساتذته في كلية الآداب حفزوه على ترجمة كتاب دي

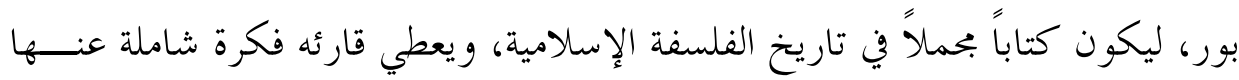

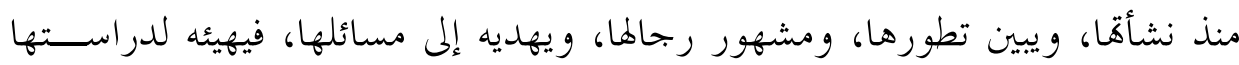

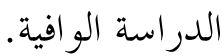

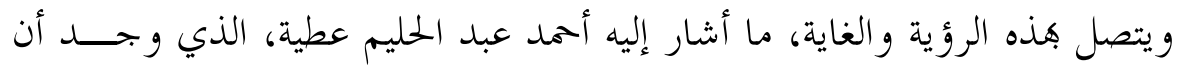

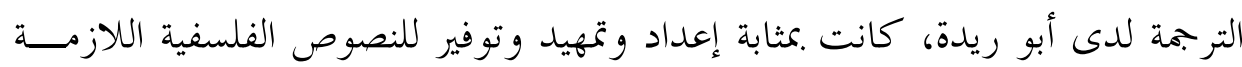

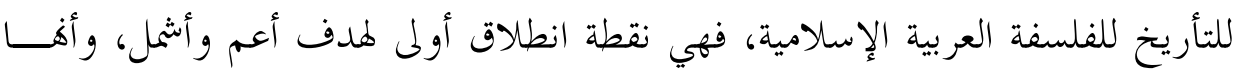
جهد فلسفي في الأساس من حيث توظيف الأدوات البحثية المختلفة، ومراجعة المصادر الفلسفية باللغات المختلفة، و الاعتماد على المخطوطات الأصلية والاستعانة هها، وتقلديم الترجمة العربية بدراسة وافية، تضع النص المترجم في سياقه في تاريخ الفلسفة الإسلامية و مشكلاكتا.

ومن جهته عدّ دي بور أن كتابه يمثل أول محاولة لبيان تاريخ الفلسفة الإســلامية

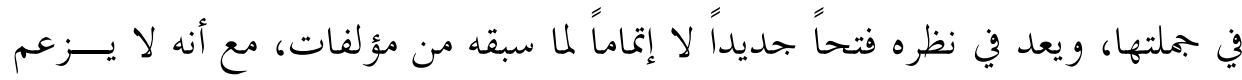

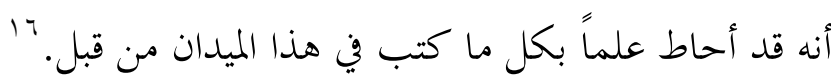
وحين توقف الدكتور الجابري أمام توصيف دي بور، وجدد أنه بالفعل يمثل فتحاً

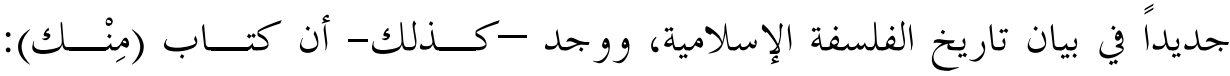

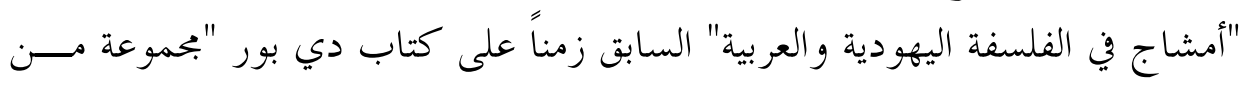

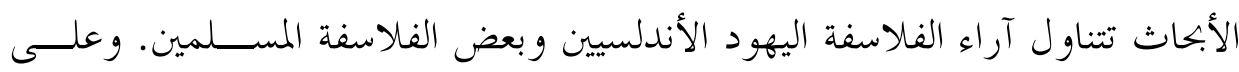
؛' بور، دي. تاريخ الفلسفة في الإسلام، ترجمة: محمد عبد الهادي أبو ريدة، بيروت: دار النهضة العربيـة، طس،

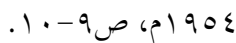

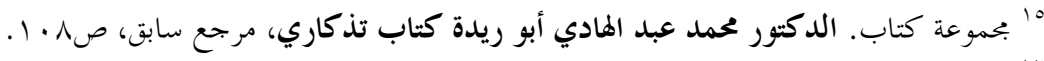

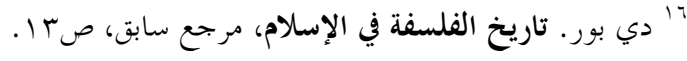




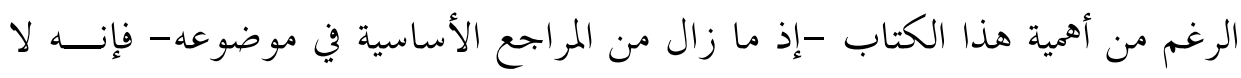

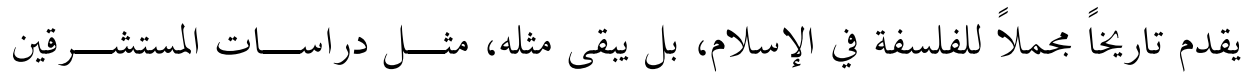

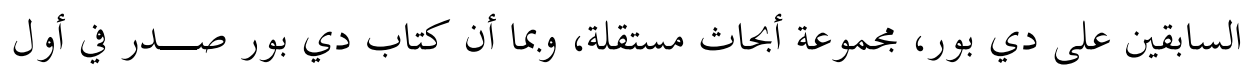

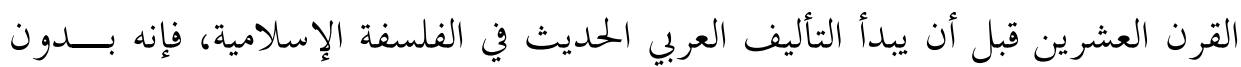

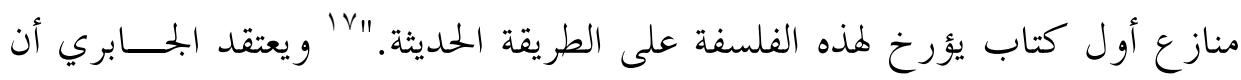

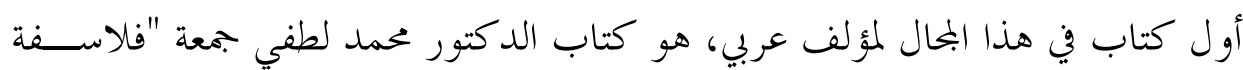

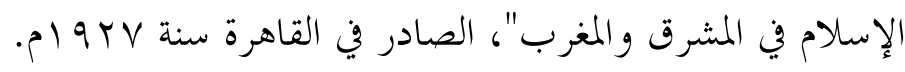

\section{رابعاً: الكتاب ومحتوياته}

يتألف الكتاب من مقدمة وسبعة أبواب، كل باب يتضمن عدة فصول. الأبواب

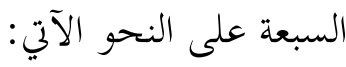

الباب الأول، وحمل عنو ان (مدخل)، واحتوى على ثلاثة فصول؛ الفصـلـل الأول

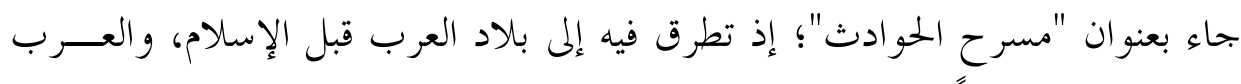

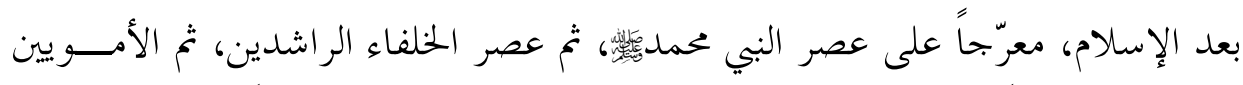

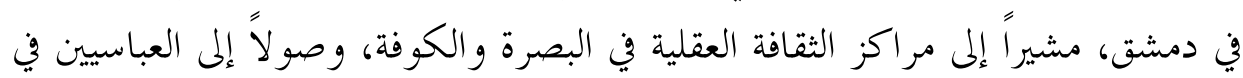

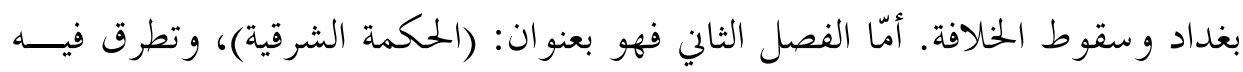

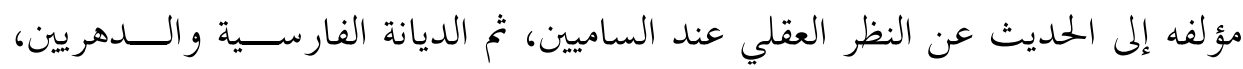

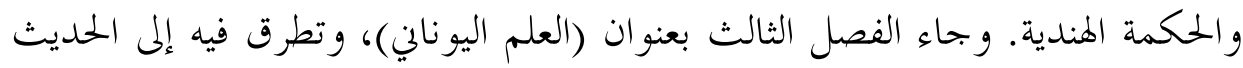

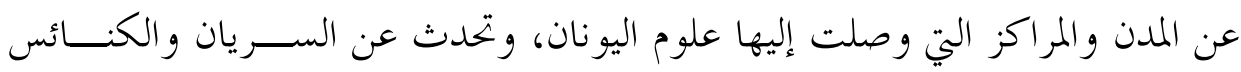

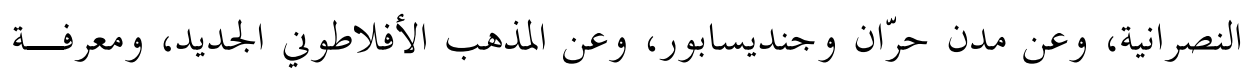

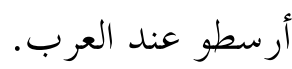

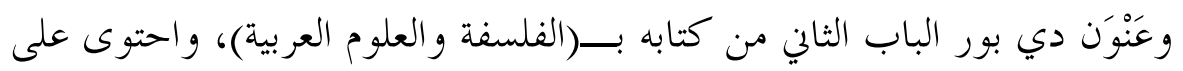

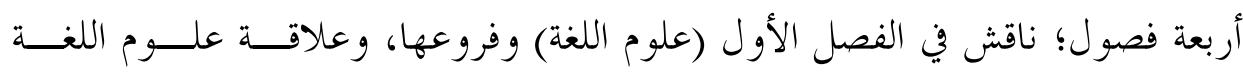


بالقر آن و بالمنطق و الفلسفة. و استوعب في الفصل الثاني (مذاهب الفقهاء)؛ إذ عــرّج

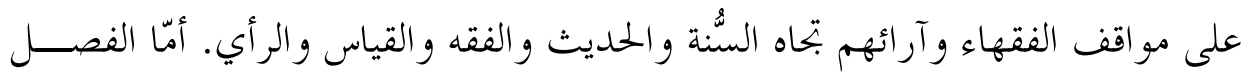

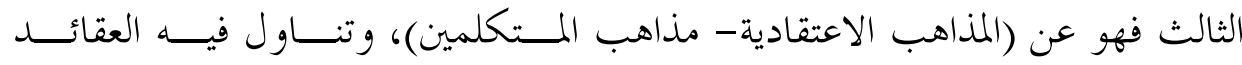

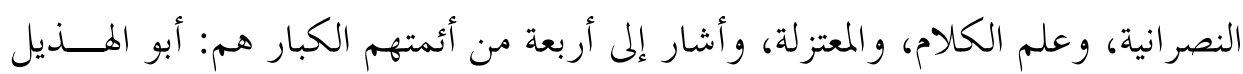

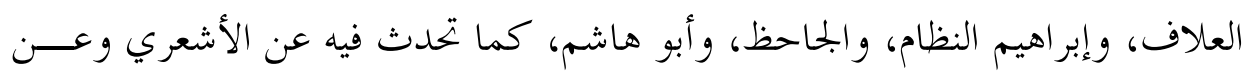
التصوف.

و جاء الفصل الرابع بعنوان (الأدب و التاريخ)، و وجاء فيه على ذكر أربعة من أئمة

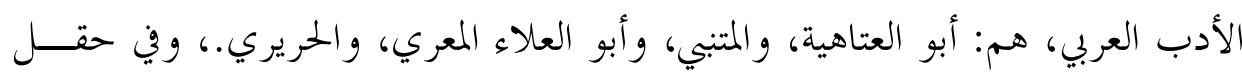
التاريخ تحدث عن المسعودي والمقدسي. و احتوى الباب الثالث: (الفلسفة الفيثاغورية) على فصلين؛ الفصل الأول منـــهما

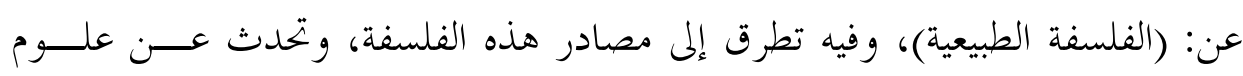

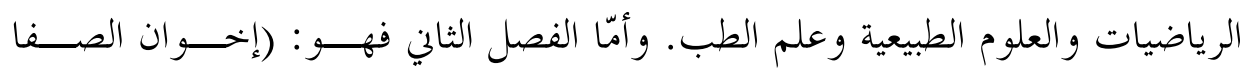

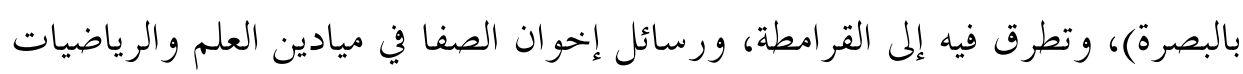

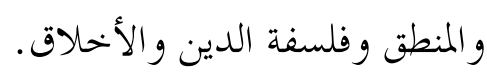

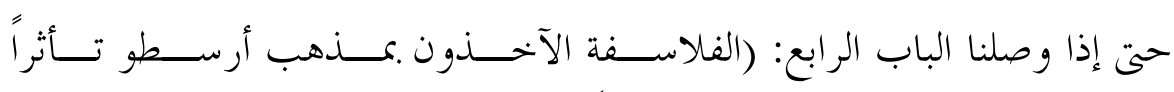
بالأفلاطونية الجلديدة في المشرق) ألفيناه محتوياً على خمسة فصول، عرض في كل فل فصل

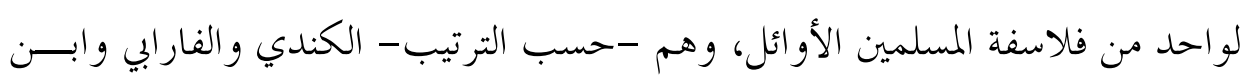
مسكو يه وابن سينا و ابن الهيثم.

و في الباب الخامس يجد القارئ آفاقاً من الحديث عن (هاية الفلسفة في المشـــرق)،

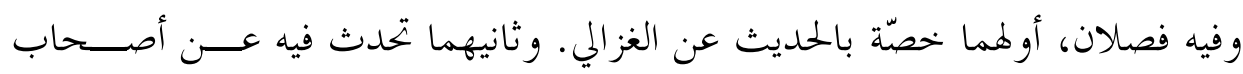
المختصرات الجحامعة.

وحمل الباب السادس عنوان: (الفلسفة في المغرب)، واحتوى على أربعة فصول.،

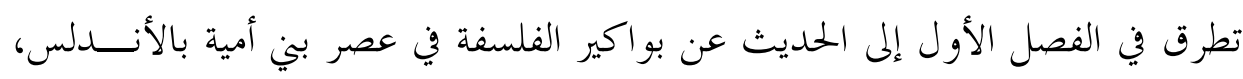




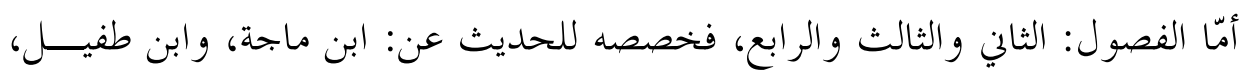
وابن رشد، على التوالي.

وختم كتابه بالباب السابع والأخير (خاتمة) واشتمل على فصــلين؛ تحـــث في

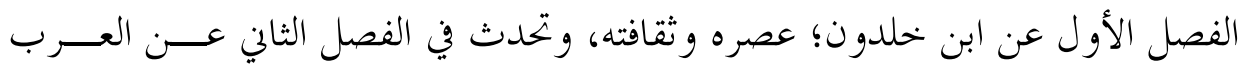

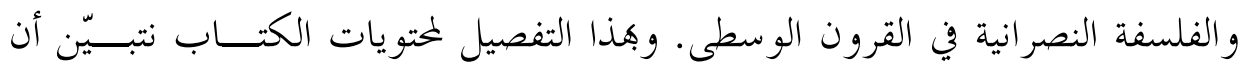

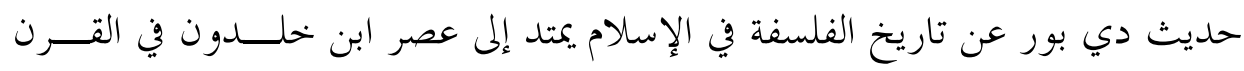

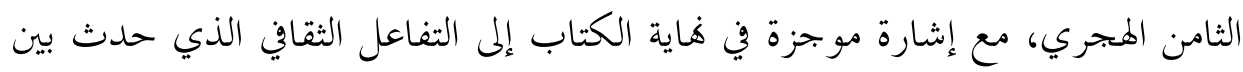

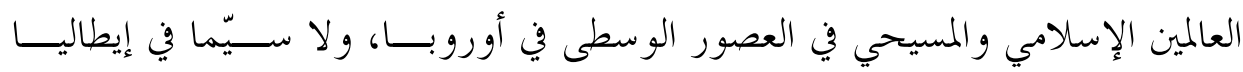

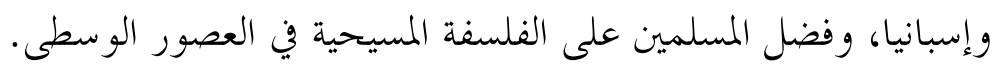

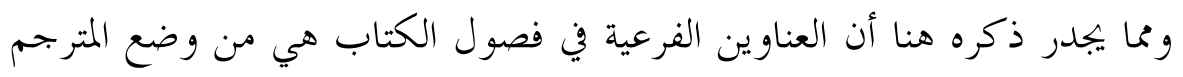

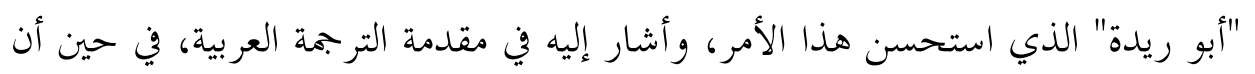
صاحب الكتاب اكتفى بذكر أرقام بدلاً من العناوين.

\section{خامساً: الفلسفة في الإسلام.. الرؤية الكلية}

قبل فاية الباب الأول من كتابه، شرح دي بور رؤيته الكلية لفكرة الفلســفة في

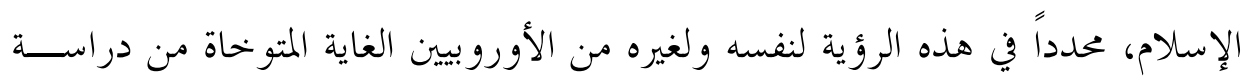
الفلسفة في الإسلام، و كاشفاً عن حقيقة دو افعه التي يخاطب بها الأوربيين خاصّة. وعن هذه الرؤية يقول دي بور: "ظلت الفلسفة الإسلامية على الــــوام فلســفة

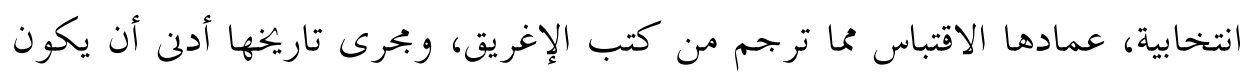

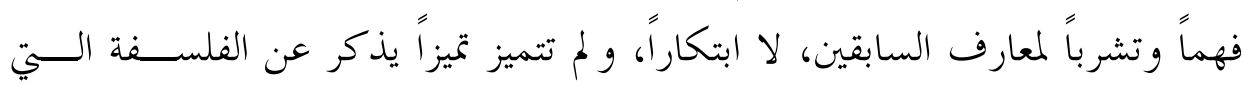

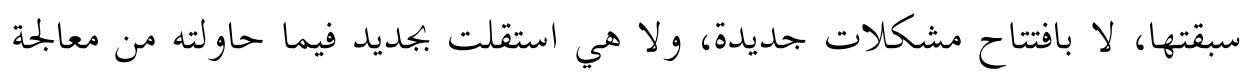

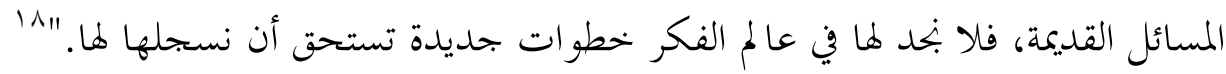




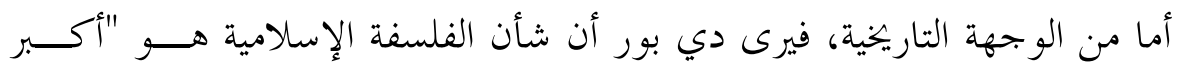

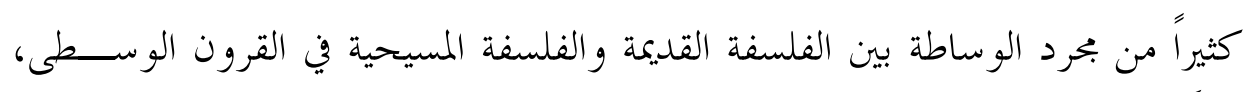

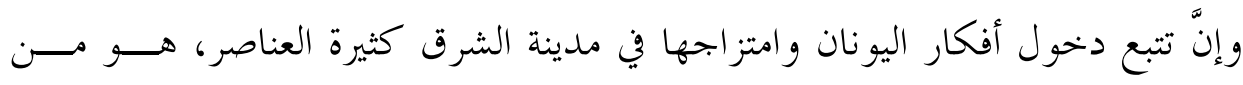

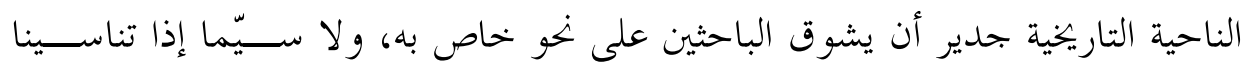

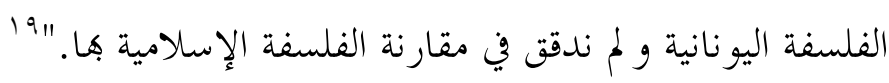

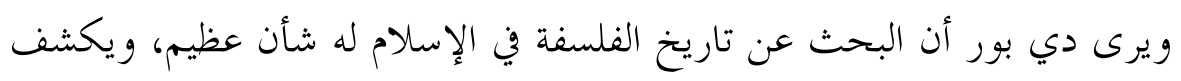

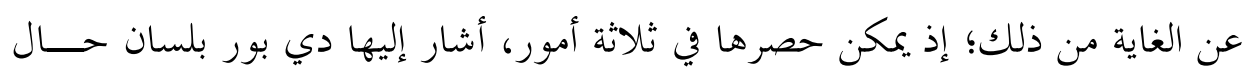

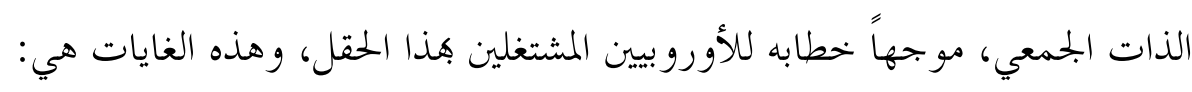
1. إتاحة الفرصة لمقارنة المدنية الإسلامية بغيرها من المدنيات، والفلسفة ظاهرة في

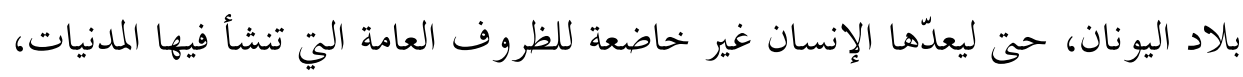

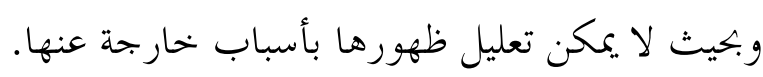

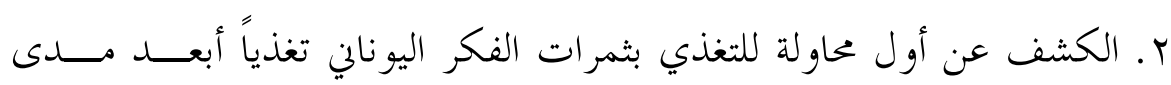

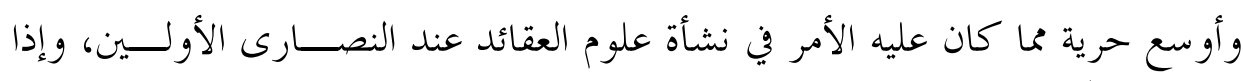

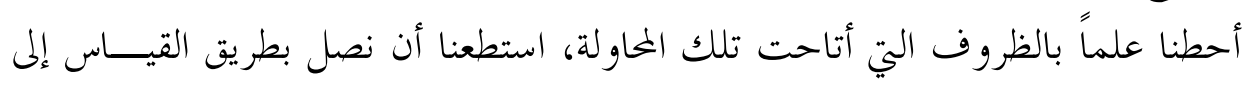

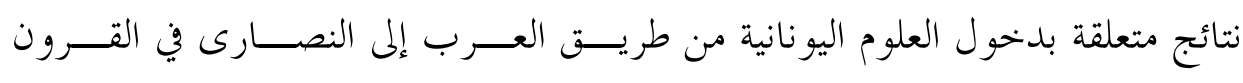

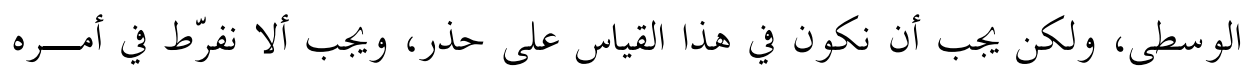

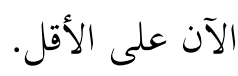
r. التعريف بالظروف التي تفيد العلم، وبالعوامل التي بتأثيرها تنشأ الفلســفة في الجملة.r وحين يتمم دي بور رؤيته الكلية، يختم حديثه بالقول "ونكاد لا نستطيع أن نقول

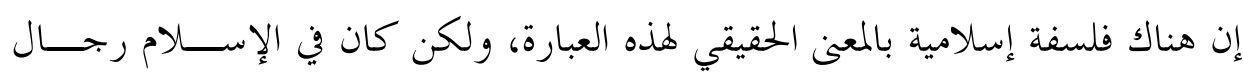

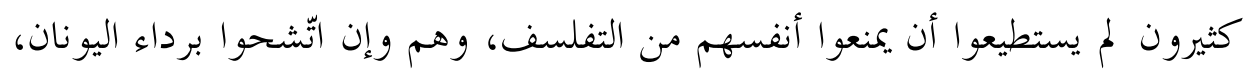

$$
\text { •" بالمرجع السابق، صبه، الصفحة نفسها. }
$$


فإن رداء اليونان لا يخفي ملامعهم الخاصة، ومن اليسير علينا أن نستهين هـم إذا أطللنا

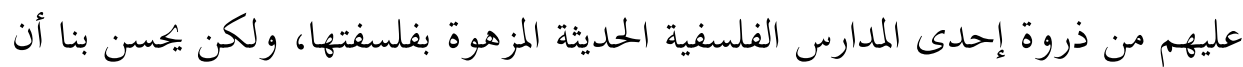

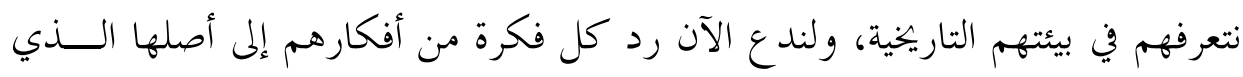

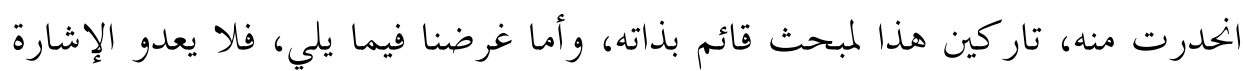

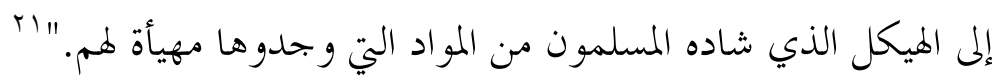
هذا النص القصير الذي عَنْوَنَهُ أبو ريدة بـــالفلسفة في الإسلام"، -و يعــادل في

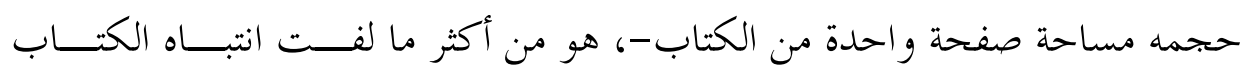

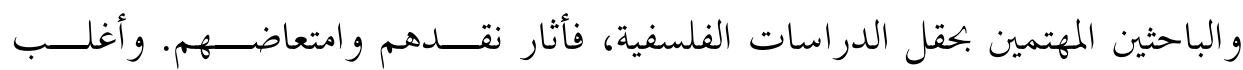

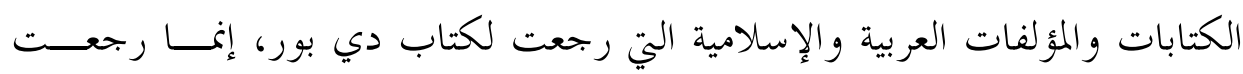

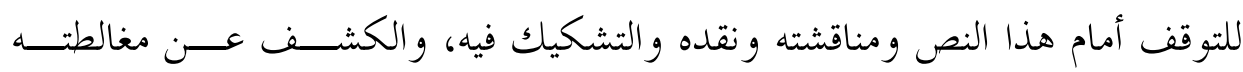

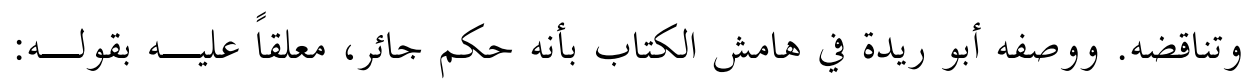

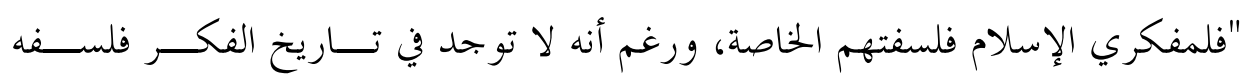

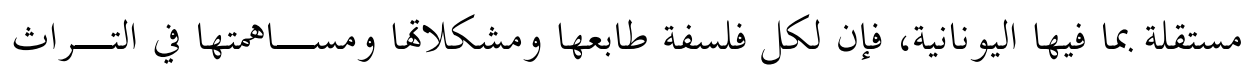

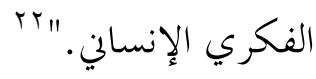

ولولا هذا الموقف المتعالي والمتحيز تجاه الفلسفة الإسلامية، لكان الانطباع العـام عن الكاتب والكتاب في البحال العربي والإسلامي مختلفاً على ما يبدو.

\section{سادساً: تعليقات المترجم... مو اقف وانطباعات}

احتوت الترجمة العربية لكتاب دي بور على تعليقات كثيرة، متفاوته في طوهـــا،

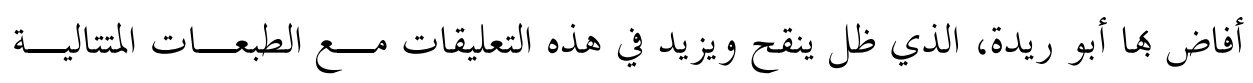

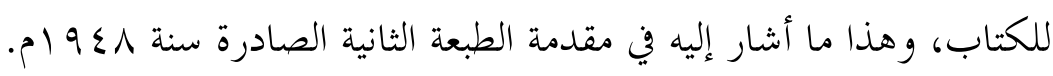
وعند النظر في هذه التعليقات يمكن تقسيمها إلى قسمين:

$$
\begin{aligned}
& \text { اr المرجع السابق، صعـه } \\
& \text { r r المرجع السابق، صعُ المابق، صع. }
\end{aligned}
$$




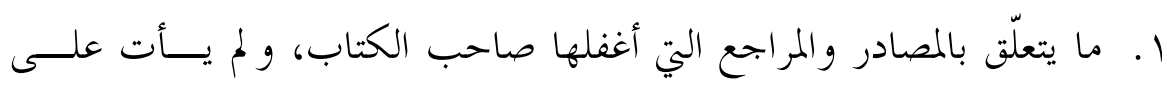

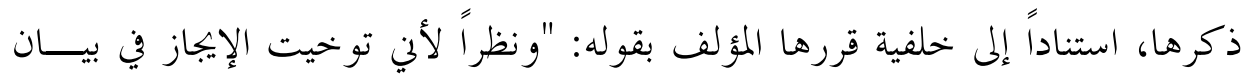

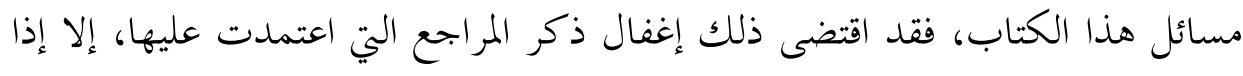

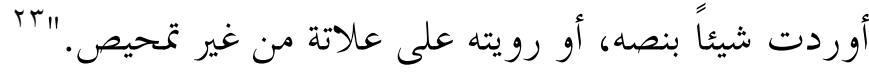

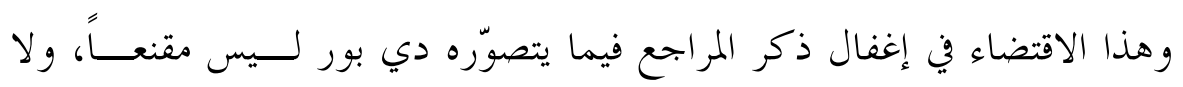

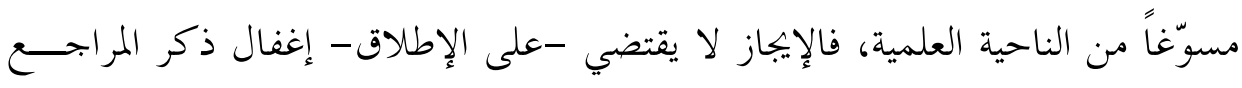
التي لا يكتمل العمل من دوها، ويعدّ نقصاً في المنهجية العلمية.

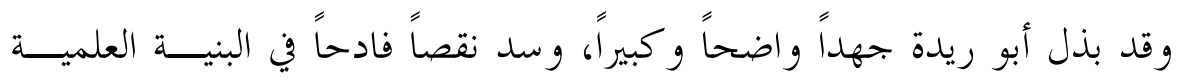

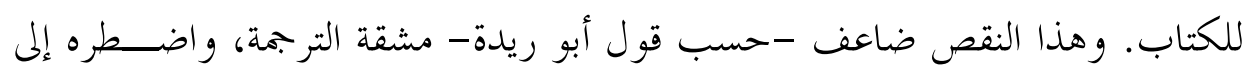

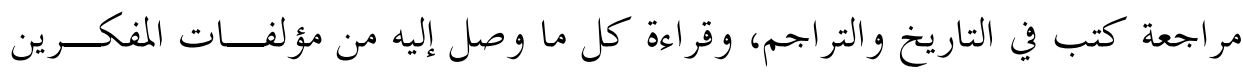

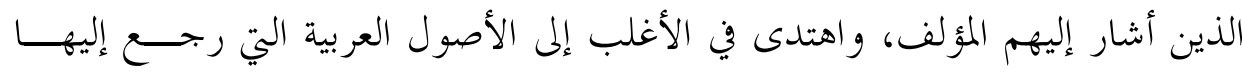

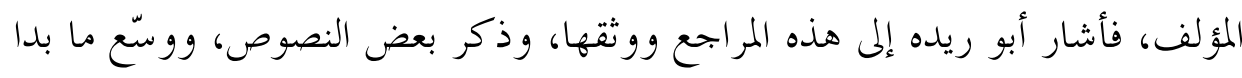

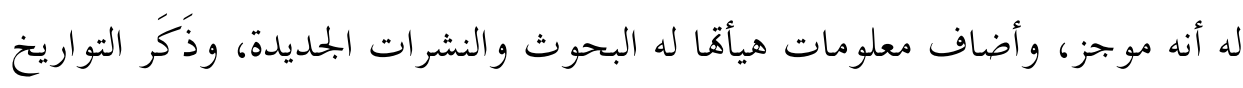
العربية مستنداً إلى المصادر العربية نفسها.

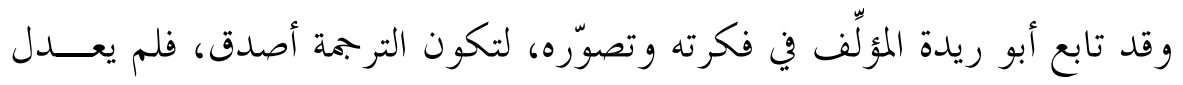

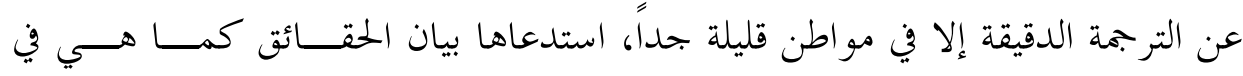

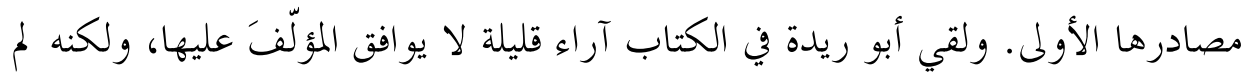

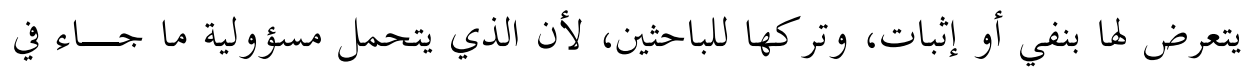

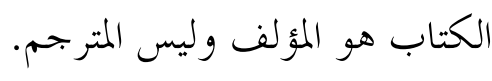
و بعد أن أتم أبو ريدة ترجمته، عرضها على أستاذه الشيخ مصطفى عبد الـــرازق،

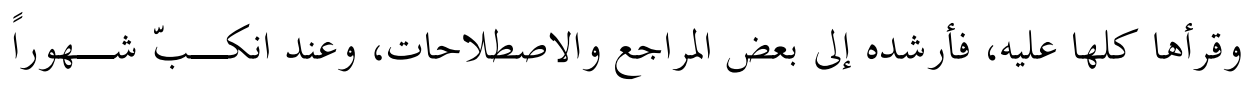

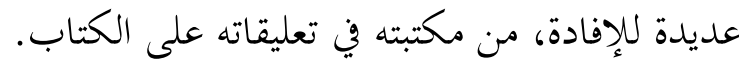


ولا شكّ في أن أبو ريدة في هذا القسم من التعليقات قدم خدمة جليلة لدي بور،

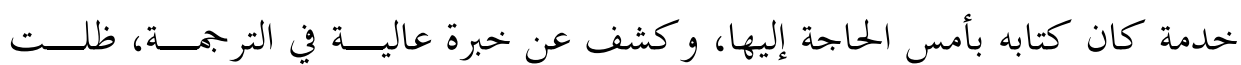

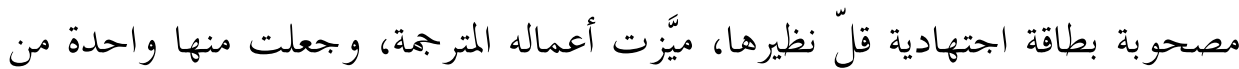
أفضل الترجمات ضبطاً و إتقاناً و إحكاماً.

r. . ما يتعلق بالتوضيحات والإضافات والشروح و الاعتراضات التي تراوحت بين

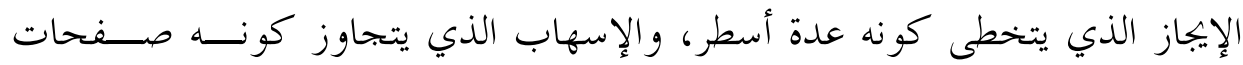
طويلة، وصل بعضها إلى أربع عشرة صفحة متتالية.

و يتصل هذا التعليق برأي دي بور في ما أسماه بتقلّب الظروف التي عـــاش فيهـــا

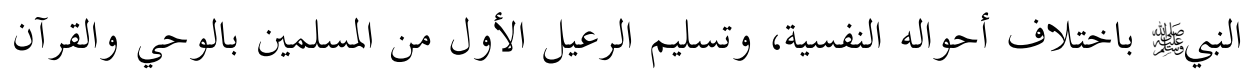

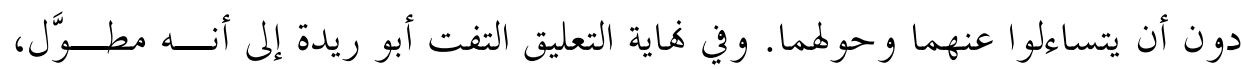

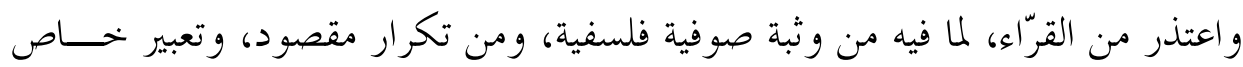

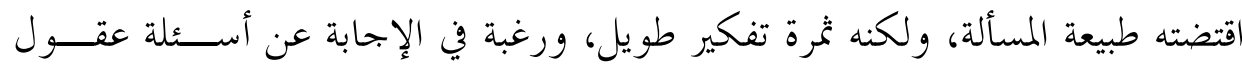

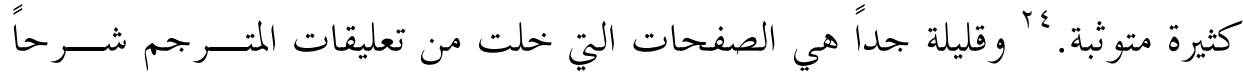

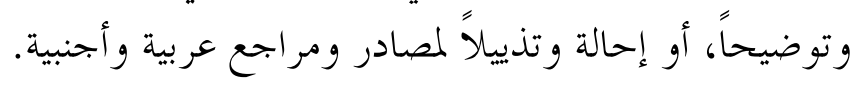

هذه التعليقات لفتت انتباه الذين طالعوا الكتاب، أو الذين رجعو ا إليه بصورة من الصور، وتوقفوا عندها، وعدّوها إحدى السمات التي تميزت هها ترجمات "أبو ريدة".

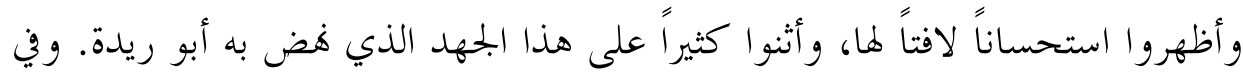

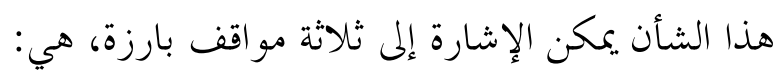
أ. ما أشار إليه علي سامي النشار من أن "عممد عبد الهادي أبو ريدة إنما يصــــر

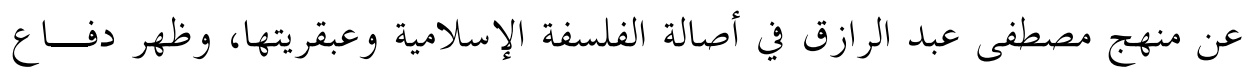
محمد عبد الهادي أبو ريدة عن أصالة الفلسفة الإسلامية واستقلالها، في تعليقاته الزاخرة

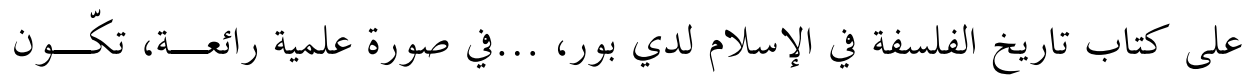
كتاباً منفصلاً عن الكتاب الأصلي. "ro" 
ب. وصف فؤاد زكريا ترجمات "أبو ريدة" بالرائعة، ورأى أنه "مــن الصــعب

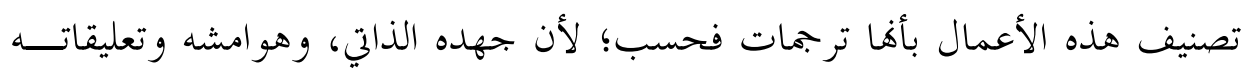

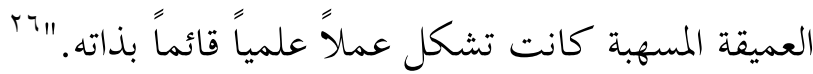

ت. ما أشار إليه أحمد عبد الحليم عطية حين رأى أن جهد "أبو ريدة" في ترجمته

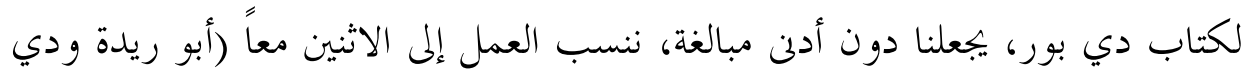

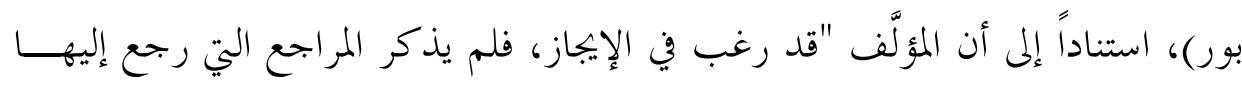

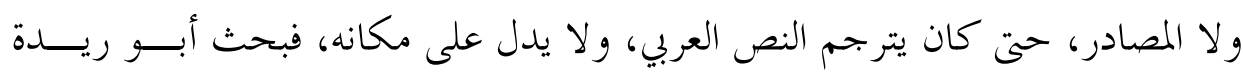

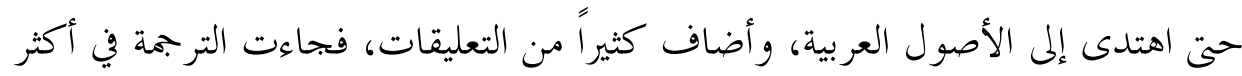
من ضعفي حجمها الأصلي، مزودة بالإشارات والتنبيهات والتعليقات، ووسَّع ما هو موجز، وأضاف معلومات هيأها البحوث الجلديدة، حتى جاء الكتاب أوفى وأعمّ نفعاً، و بداية لجههده في تأريخ أوسع للفكر الإسلامي.

و الموقف الذي خرج عن هذا النسق التبجيلي، هو ما أشار إليه ماجـــــ فخــــي، الذي أخذ على المترجم التجّرد للرد على صاحب الكتاب بإسهاب في بعض الأحوال

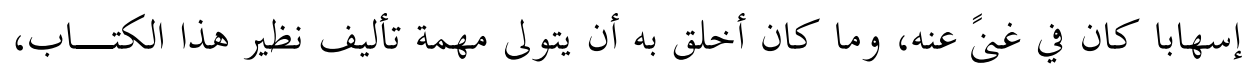
ما دام له في شأنه مثل هذه التحفظات.

وهذا ما توصل إليه لاحقاً أبو ريدة نفسه؛ إذ وجد أن من الأولى بعد طول الكلام

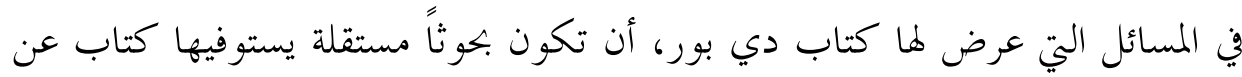

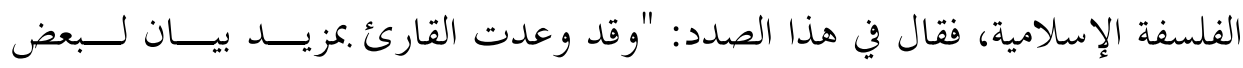

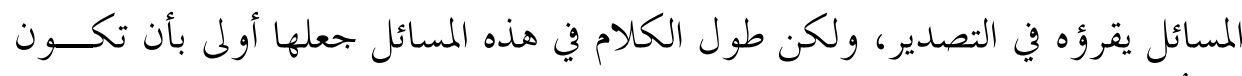

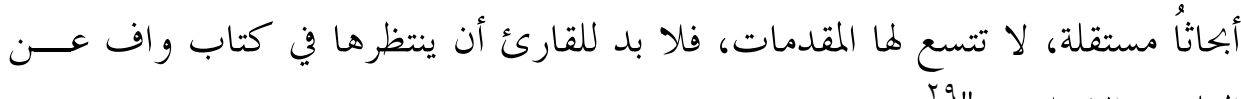

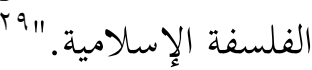

"rr بحموعة كتاب. الدكتور محمد عبد الهادي أبو ريدة كتاب تذكاري، مرجع سابق، ص9 ا.

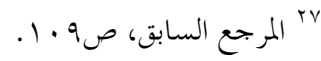

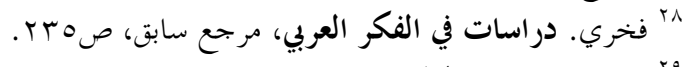

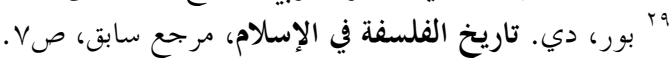




\section{سابعاً: ملاحظات على التعليقات}

كنت قد توقفت أمام تعليقات "أبو ريدة"، و بدت لي بعض الملاحظات المتَّصــلة

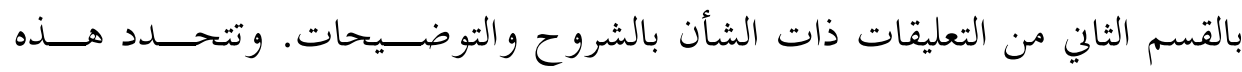

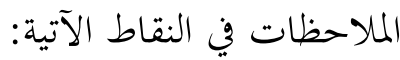

ا ـ من المعروف عند المشتغلين في حقل الترجمة، أن هناك طريقتين متبعستين في إبداء الملاحظات و التعليقات على الأعمال المترجمة: أ. الطريقة الأولى: وهي التي اتبعها أبو ريدة في هذا الكتاب؛ إذ تتوزع الملاحظات

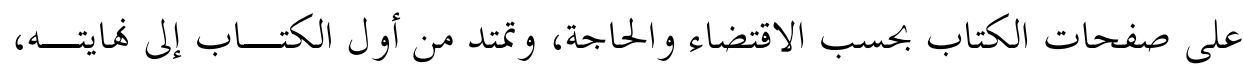
وتقرأ هذه الملاحظات متصلة مع نص الكتاب في الهوامش المخصصة لها. ب. الطريقة الثانية: أن يجمع المترجم ملاحظاته وتعليقاته في نص و احد يُصدَّر به الكتاب عادة، فتنفصل الملاحظات والتعليقات عن نص الكتاب. وهي الطريقة الأفضل

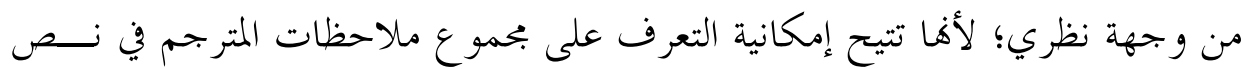
كلي موحّد ومتواتر، وليس بطريقة بتزيئية ومتفرقة بين صفحات الكتاب، ولأن هذه

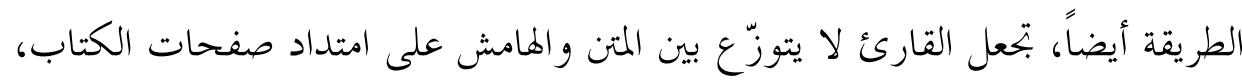

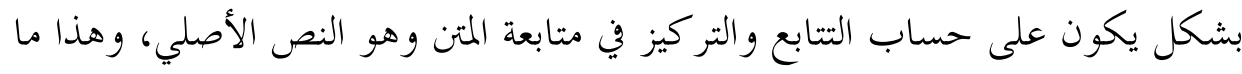

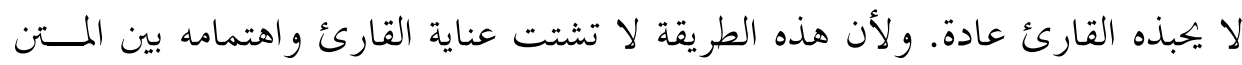

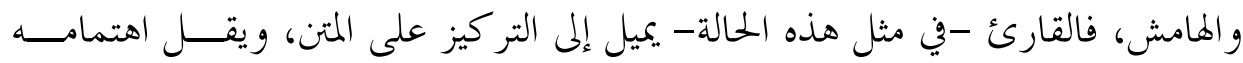
بالهامش؛ لأنّ الكتاب بمتنه وليس بكو امشه المضافة.

r. مع كثرة التعليقات والإسهاب في التوضيحات التي قدّمها أبو ريدة، إلا أنه لم يذكر شيئاً عن سيرة المؤلف ولو بمقدار سطر واحد، بل ذكره مختصراً؛ في القسم الأول منه على هذا النحو: (ت. ج. دي بور)، وليس كافياً على الإطلاق، الاكتفاء بعبـــارة

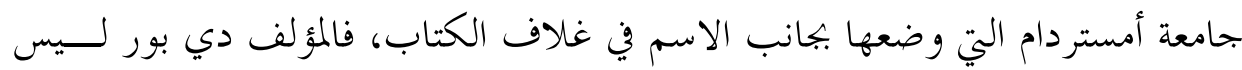

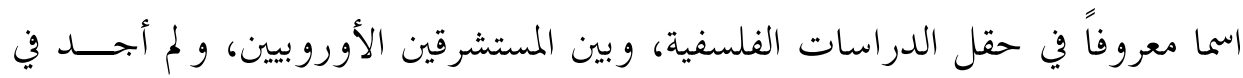


الكتابات العربية -في حدود اطلاعي- من كتب شيئاً عن سيرته، وقد أغفله كلياً عبد الرحمن بدوي، و لم يأت على ذكره في كتابه: (موسوعة المستشرقين)، الذي ترجم فيه

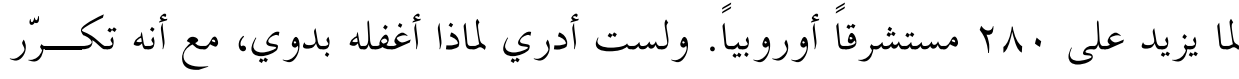
ذكره في كتابه (التراث اليوناني في الحضارة الإسلامية).

وما يؤكد صحة هذه الملاحظة، الالتباس الذي وقعت فيه الكتابات العربية بشأن

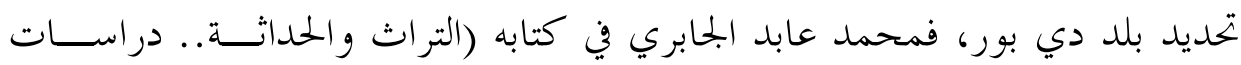

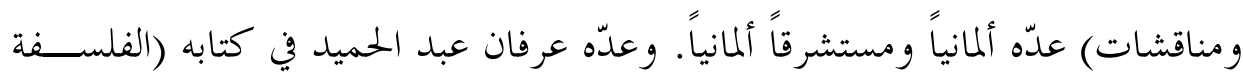

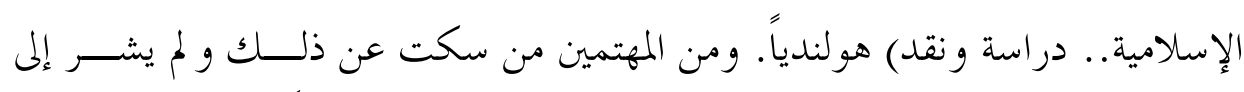

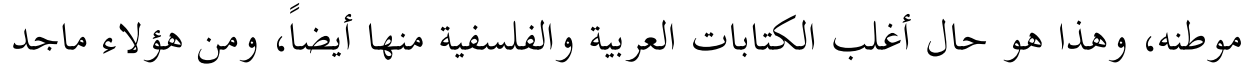

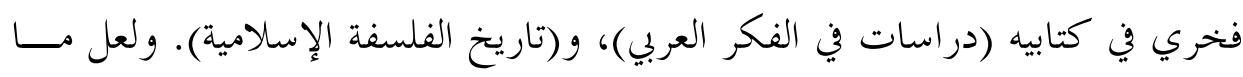
يرفع هذا الالتباس، ما أشار إليه رضوان السيد في دراسته عن الاستشراق الألماني، وفيه

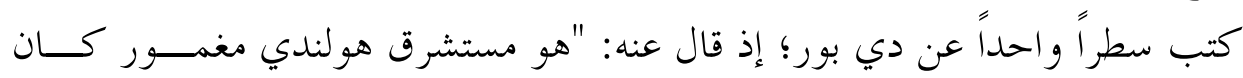

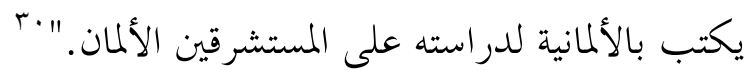

وهذا يكون أبو ريدة هو الذي عرّف العالم العربي بدي بور، و بكتابه. r. من الملاحظات التي تلفت الانتباه في تعليقات "أبو ريدة"، تلك المفارقة الكمية

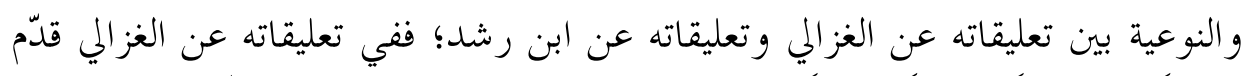

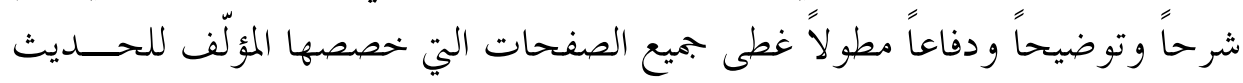

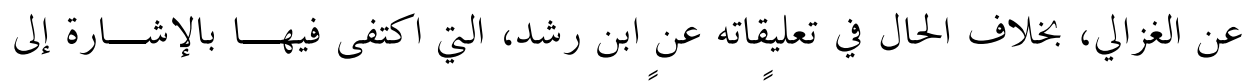

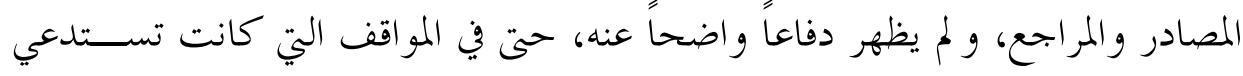
الدفاع و الشرح و التوضيح.

فقد أشار دي بور إلى مواقف خطيرة، اتم فيها ابن رشد في قوله: "وبالجملة ففي

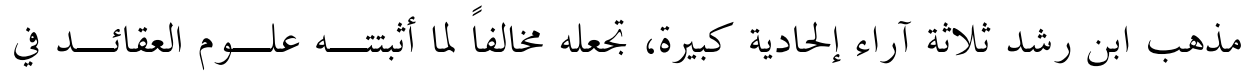

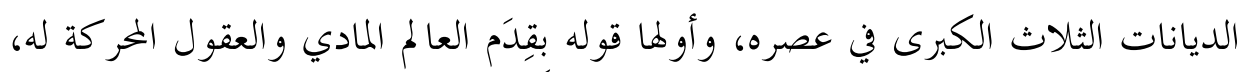

• السيد، رضوان. الثأثيرات الاستشراقية الألمانية في دراسات الفكر الفلسفي الإسلامي، مرجع سابق. 


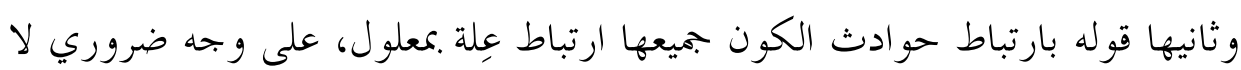

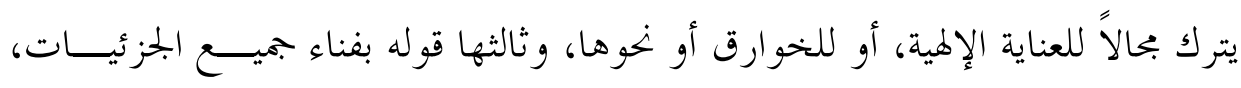

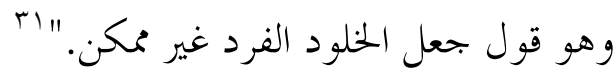

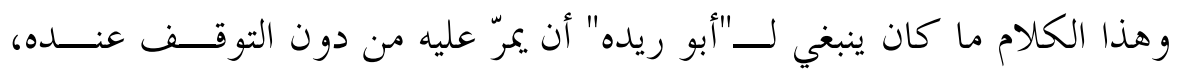
و نقضه، و التشكيك فيه.

وعندما علق دي بور على كلام ابن رشد حول العلاقة بــين الــــين و الفلســفة

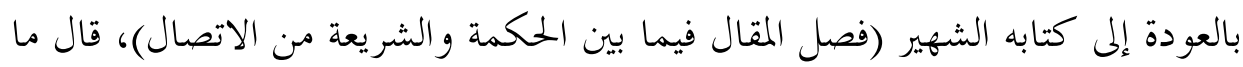

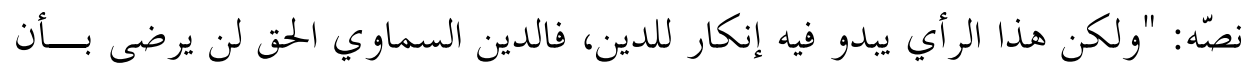

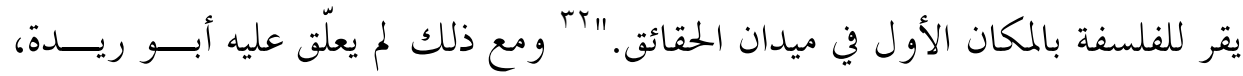

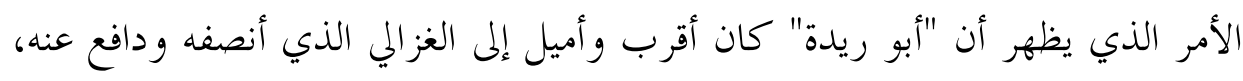

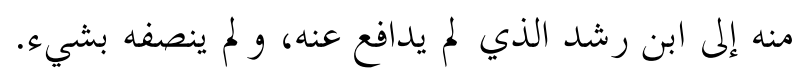

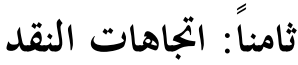

لم أجد في حدود متابعاتي في الكتابات العربية مراجعات نقدية شاملة وتفصـيلية

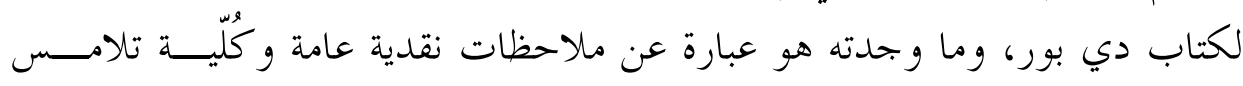

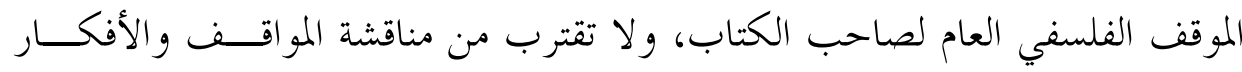

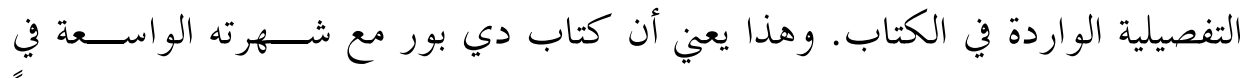

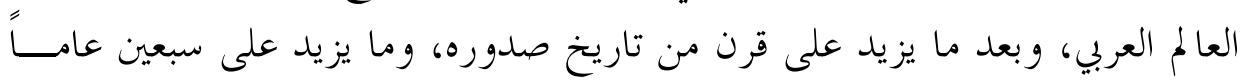

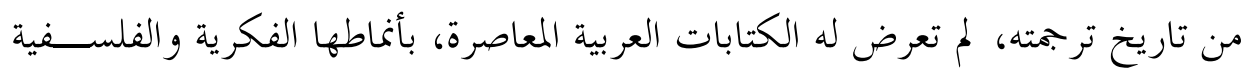

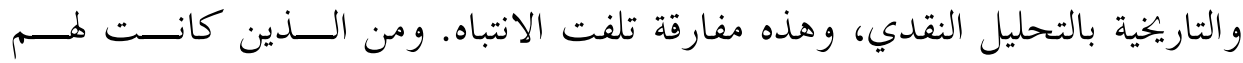
ملاحظات نقدية عامة على كتاب دي بور، إبراهيم مدكور، ومحمد عابد الجابري.

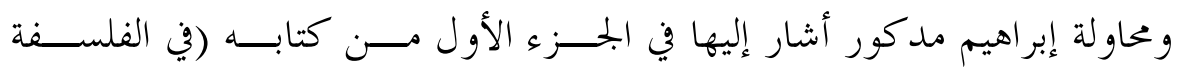

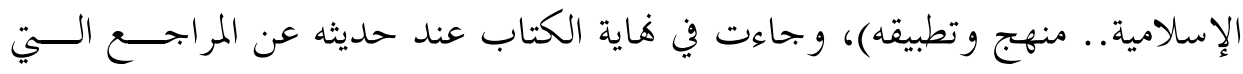

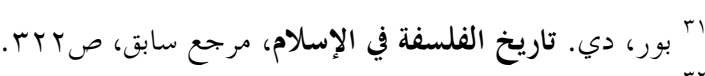

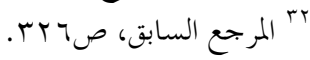


تحدثت عن الفلسفة الإسلامية ومنهج بحثها، فمع تقديره لجهود دي بــور وأتـــره في تاريخ الفلسفة الإسلامية، إلا أنه سجل عليه ملاحظتين هما:

- أنه لم تتهيأ لدي بور في أخريات القرن التاسع عشر كل المصادر التي تمكنـــه

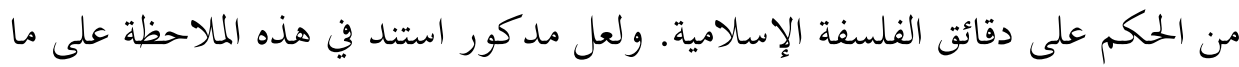

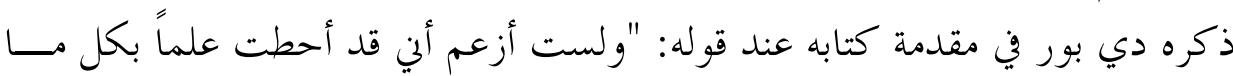

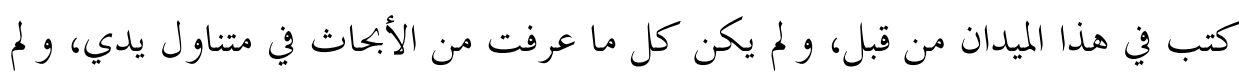

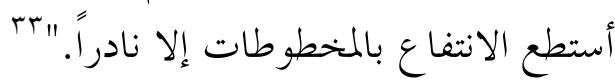

- ـ يبدو لدى مدكور أن دي بور قد غير رأيه شيئاً فشيئاً؛ ففي فصل له في دائرة

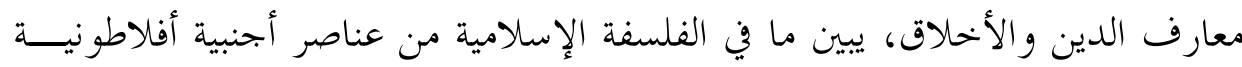

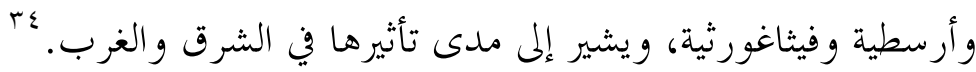

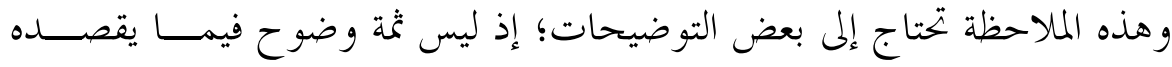

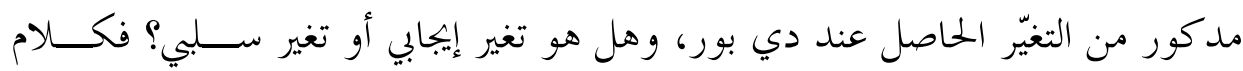

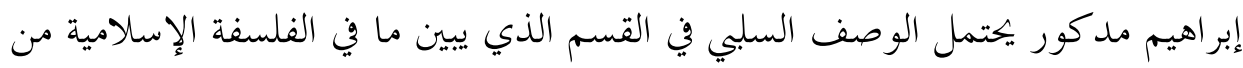

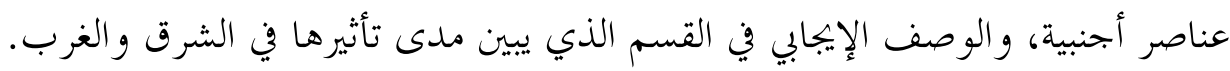
أما محاولة محمد عابد الجابري، فقد جاءت في سياق تحليل الرؤيـــة الاستشــــاقية

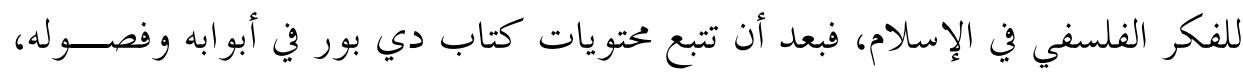
وفحص مضمونه، وتوقف عند طبيعة رؤيته لتاريخ الفلسفة في الإسلام، أشار إلى بعض بـ إلى الملاحظات النقدية التي يمكن حصرها ونوفي في أمرين أساسيين، هما:

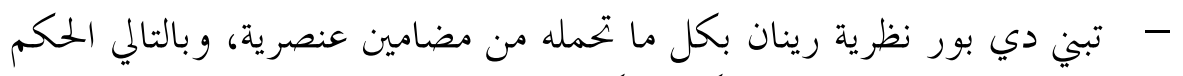

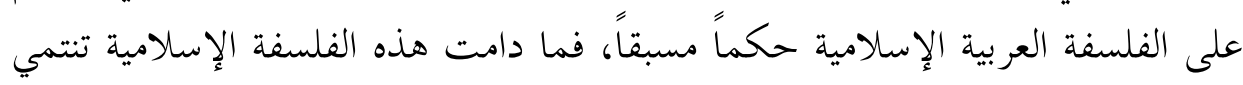

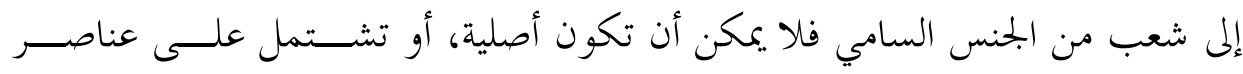

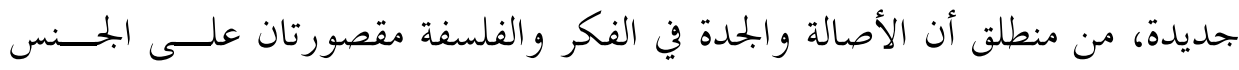

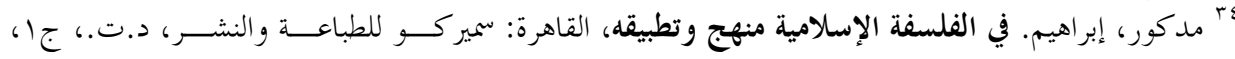


الآري وحده. وأشار دي بور إلى هذا الموقف عند قوله: "لم تكن للعقل السامي قبـلـل

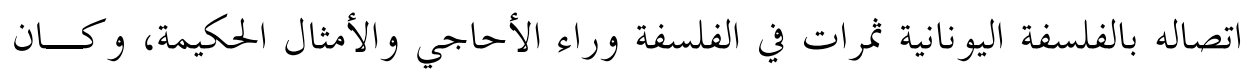

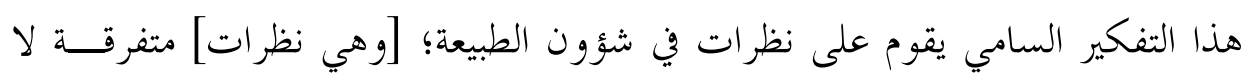

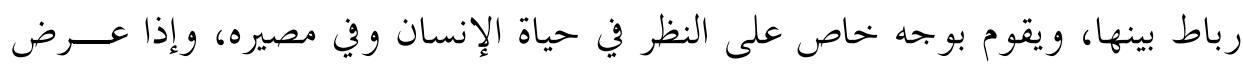

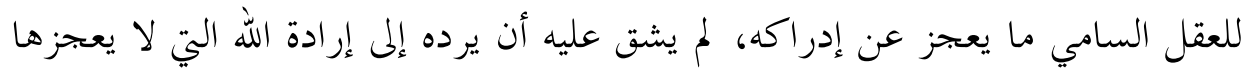

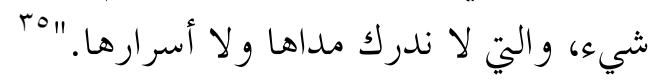

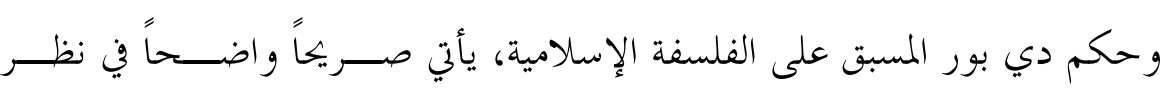

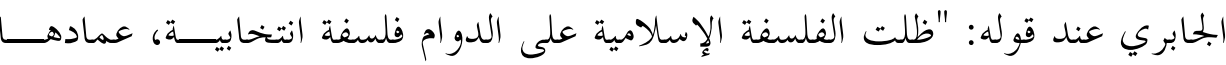

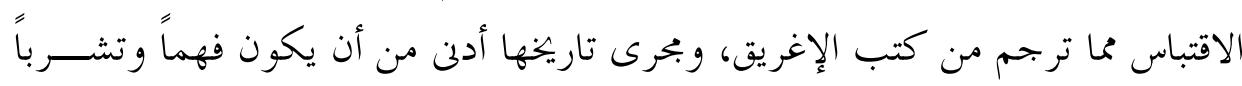

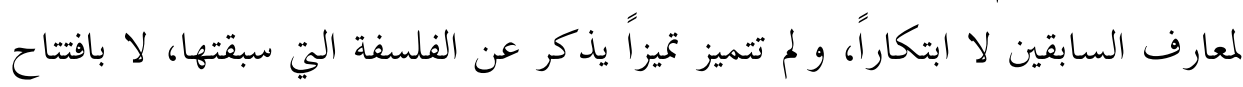

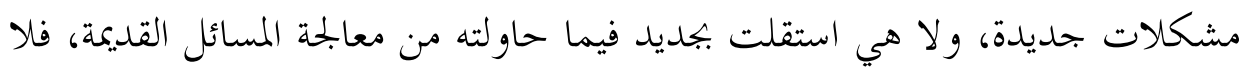

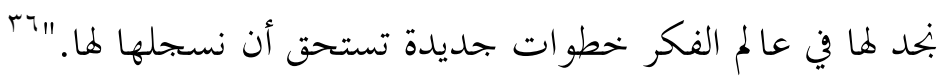
و يعقب الجابري على هذا الكلام، متسائلاً: "إذا كان كذلك، فلماذا الاهتمام هها،

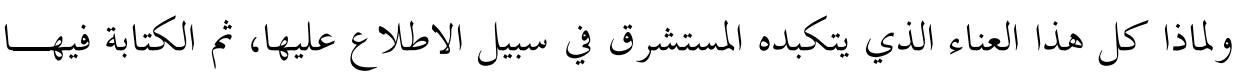
بلغته و وداخل ثنقافته؟

- إن الهدف عند دي بور كما عند غيره من المستشرقين ليس فهـــم الفلســفة

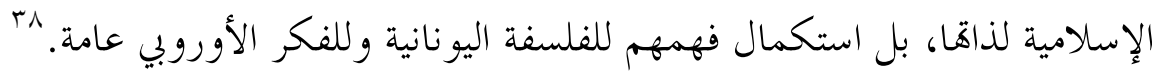
لكن هناك من رأى أن هذا النقد يرتد على الجابري نفسه.، فهذا إبراهيم العــاتي

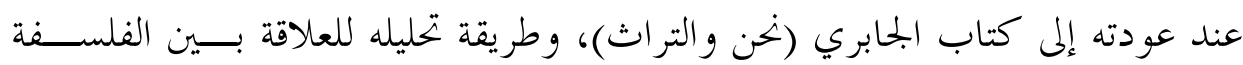

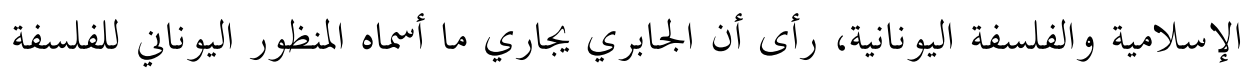

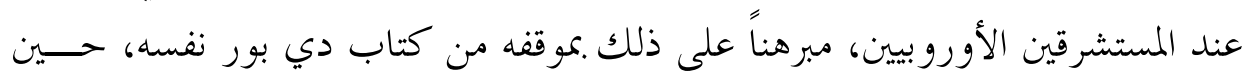

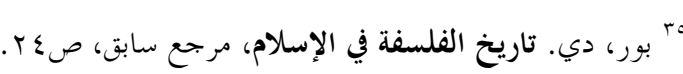

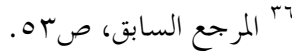

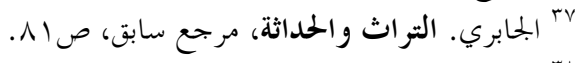

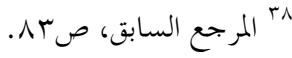


قال عنه الجابري إنه من أحسن ما كتبه المستشرقون. ووفي شرحه لهذا الموقف، يقـــول

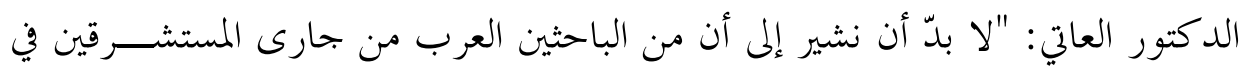

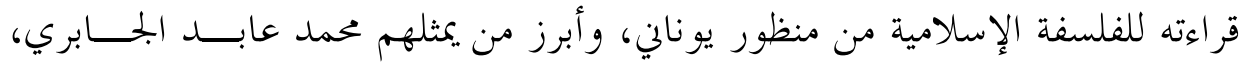

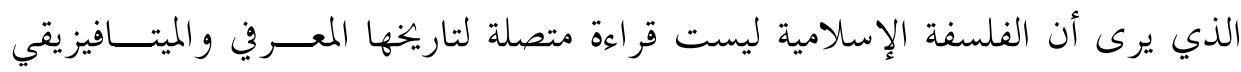

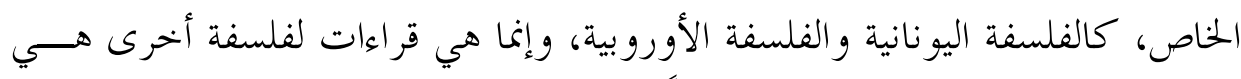

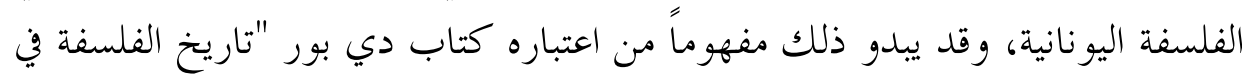

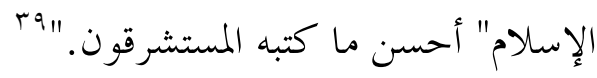

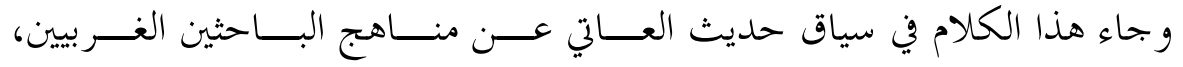

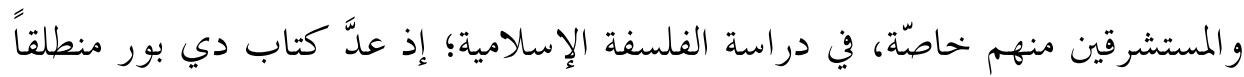

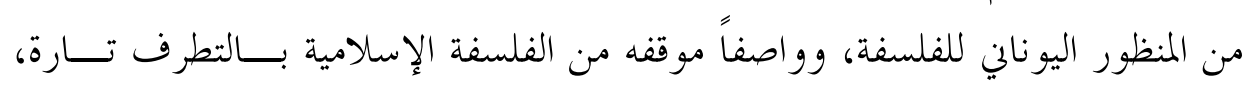

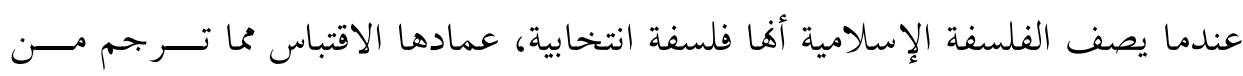

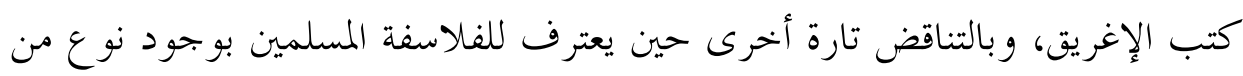

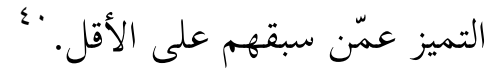

\section{تاسعاً: ملاحظات ونقد}

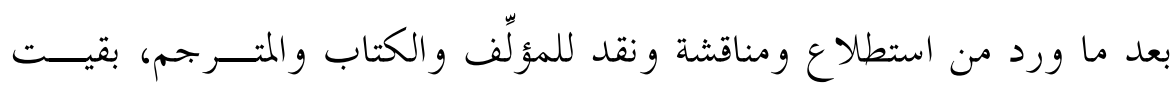

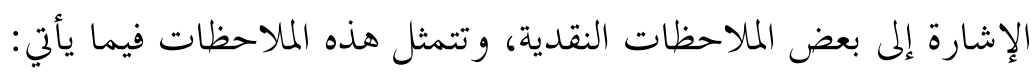

1. سعى المؤلف بشكل دائم في تأكيد التأثيرات الأجنبية اليونانيـــة والرومانيــة و النصرانية في الثقافة الإسلامية وعلومها ومعارفها، ومنها الفلسفة الإسلامية.

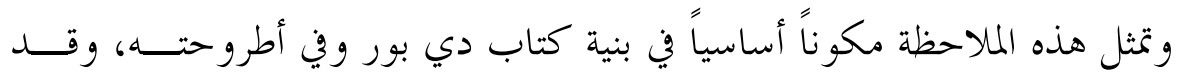

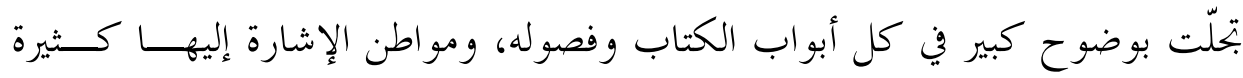

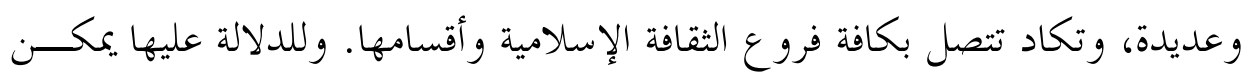
الإشارة إلى بعض الأمثلة الكاشفة على ذلك ذلك:

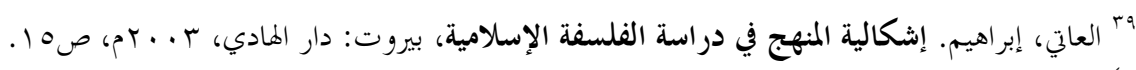

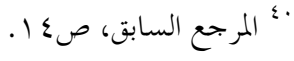


أ. حين يتحدث دي بور عن مراكز الثقافة العقلية الإسلامية، يرى أن المقرّ الأكبر

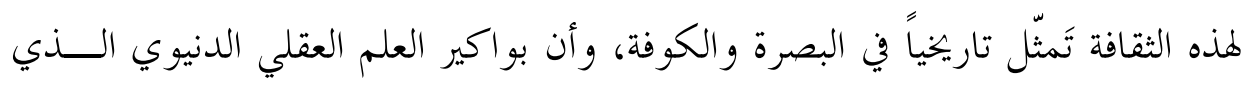

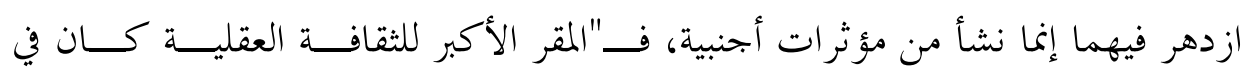

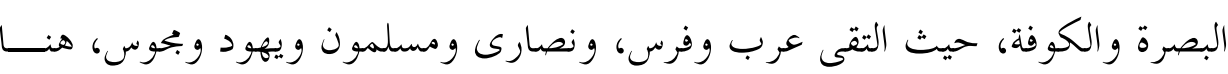

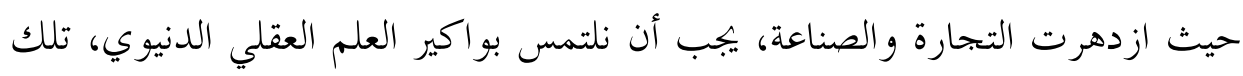
البو اكير التي نشأت من مؤثرات نصرانية مصطبغة بالفلسفة اليونانية في دورها الشرقي،

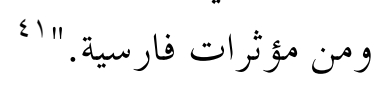

وقد عقب أبو ريدة على هذا الكلام في هامش الكتاب، معترضاً عليه ومشــكـاً

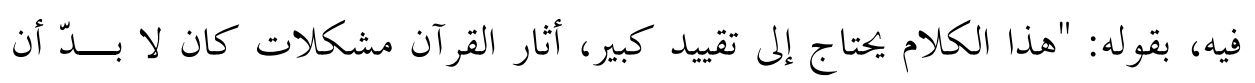

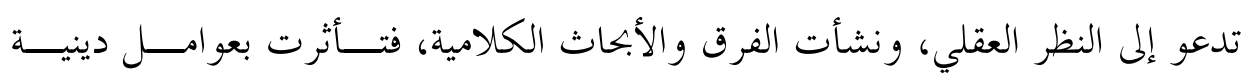

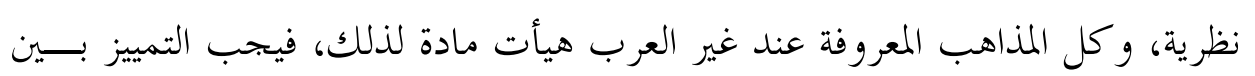

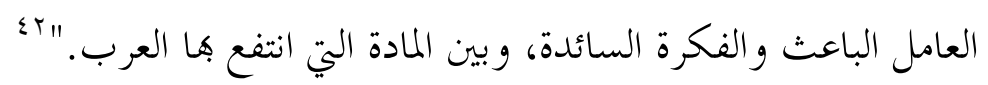

ب. حين تحدث دي بور عن أنواع العلوم، رأى أن العلوم المسماة علوم العرب،

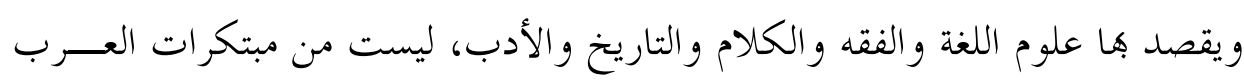

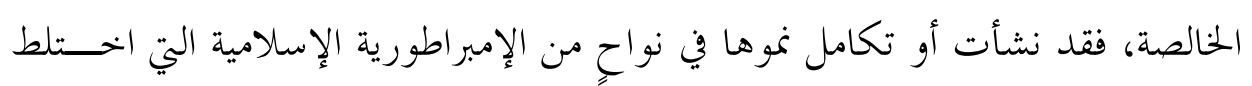

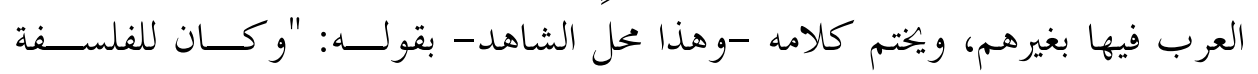

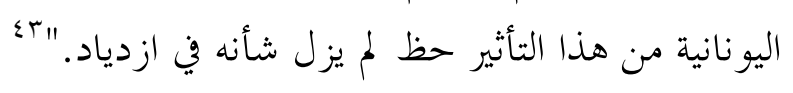

ت. عند حديثه عن المباحث الأخحلاقية في الإسلام، يقـــول دي بــور: "كـــان

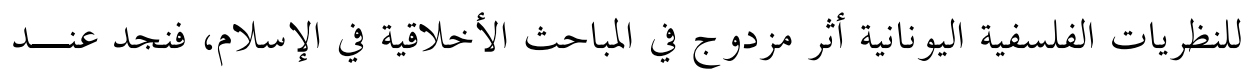

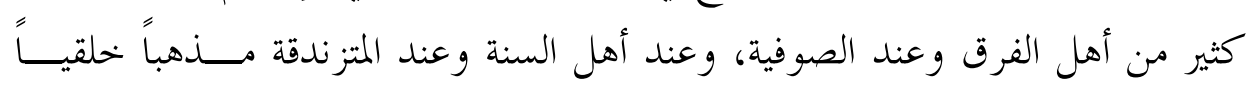

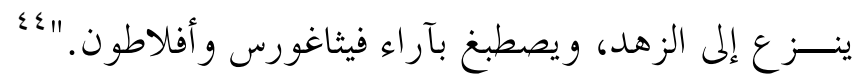

"اء بور، دي. تاريخ الفلسفة في الإسلام، مرجع سابق، صو 19.

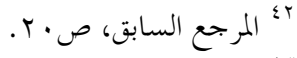

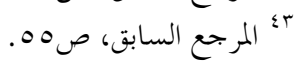

$$
\begin{aligned}
& \text { ؛؛ المرجع السابق، صعـ الساب، صه. }
\end{aligned}
$$




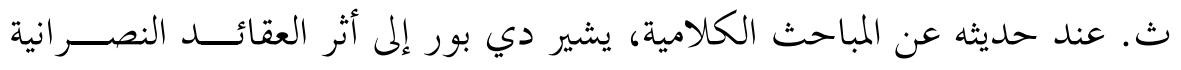

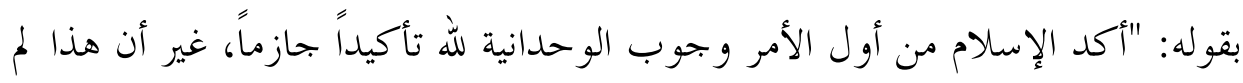

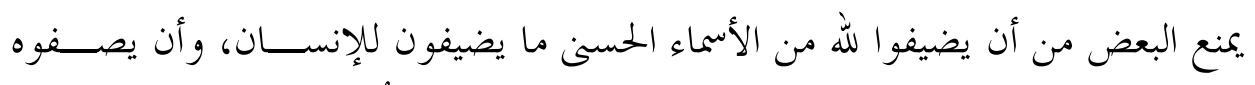

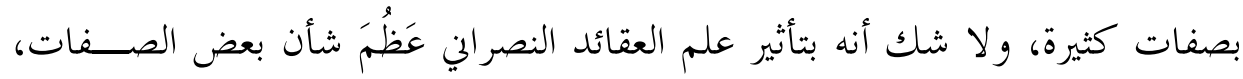

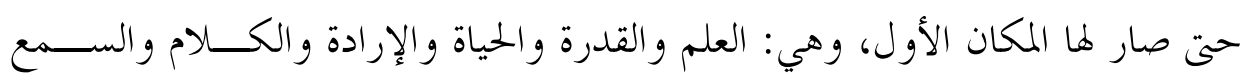

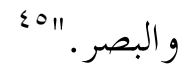

وفي تعقيبه على هذا الكاملام، يقول أبو ريدة في هامش الكتاب: "لا أرى هنا شأناً

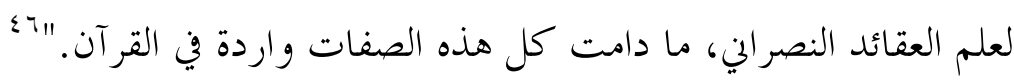

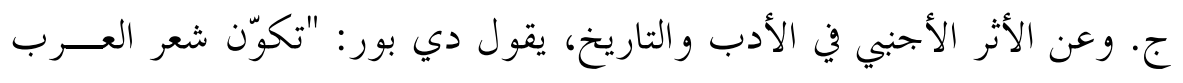

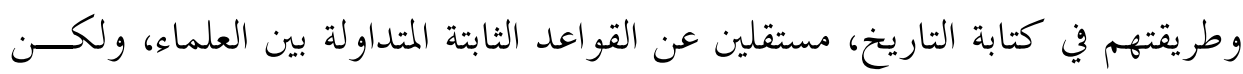

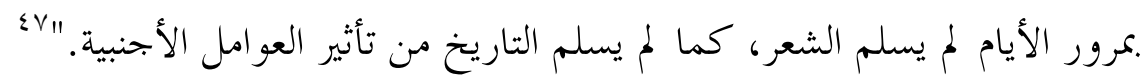
هذه بعض الشواهد والأمثلة، وهناك العديد منها في ثنايا الكتاب. من المعروف أن الملاحظة الأخيرة تعدّ من أسس الموقف الاستشراقي، فطالما تعمد

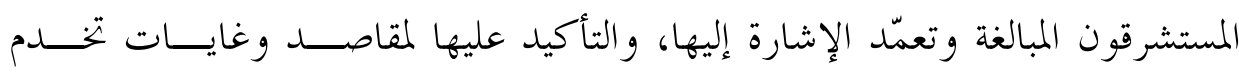

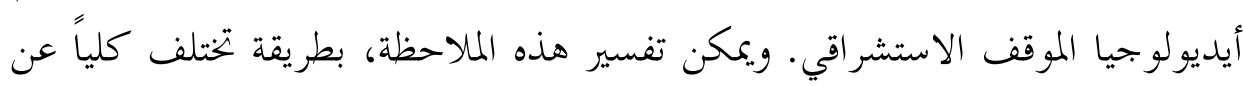
منطق الاستشراقيين، و يتحدد هذا التفسير في النقاط الآتية:

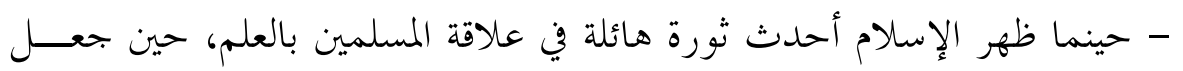

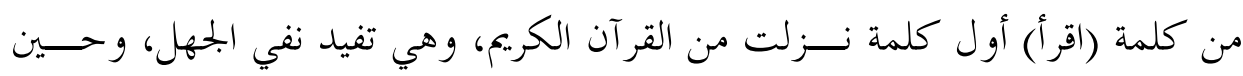

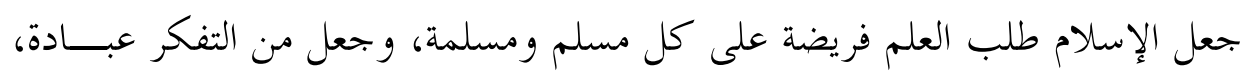

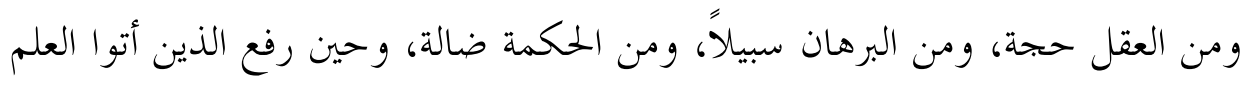

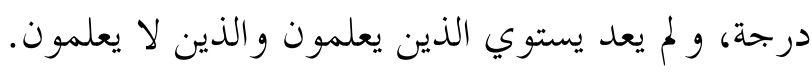

$$
\begin{aligned}
& \text { ๑؛ المرجع السابق، ص. 9. } 9 .
\end{aligned}
$$

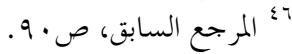

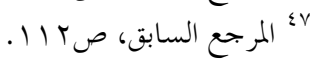


و بفضل هذه الثورة في علاقة المسلمين بالعلم، اندفع المسلمون نحو اكتساب العلوم

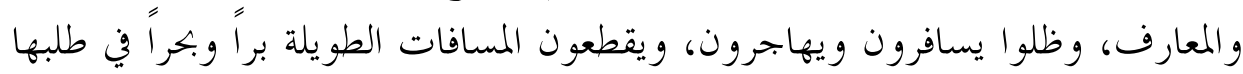

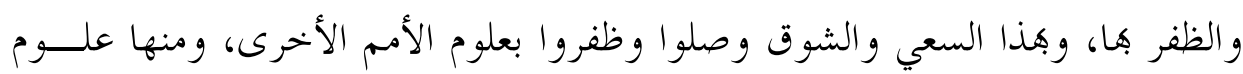
اليونان و الفرس و الهند وغيرها، و وأخذو وا منها.

- أسهم المسلمون في إحياء العلوم و المعارف التي ظفروا بها وأعادوا الروح إليها،

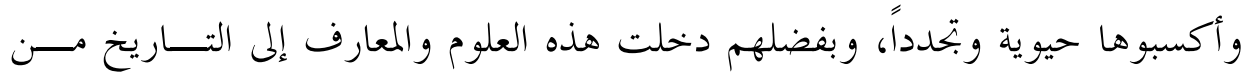

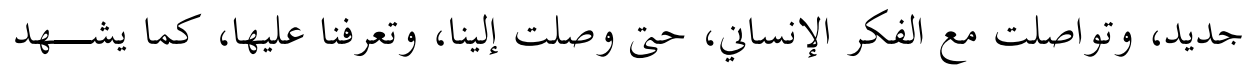

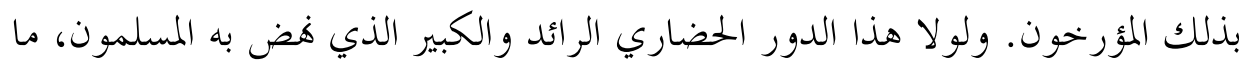

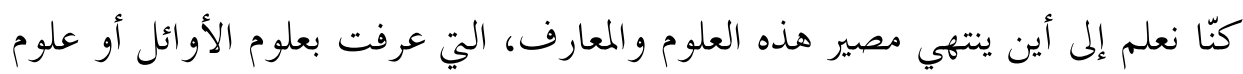

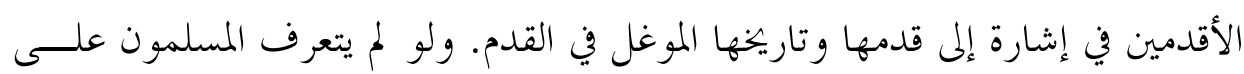

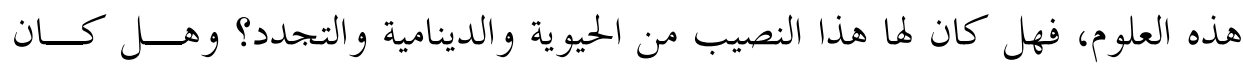

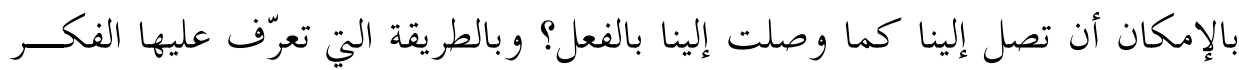
الإنساني و الفكر الأوروبي بشكل خاصل إليأ

- هذا التأثر الذي تحدث عنه دي بور وباقي المستشرقين الآخرين، إنما جاء تاليــاً

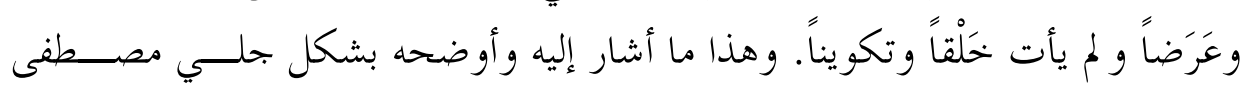

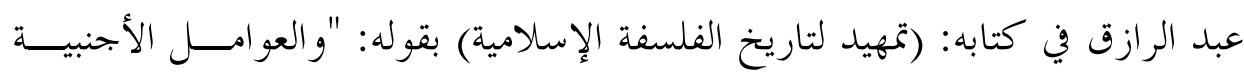

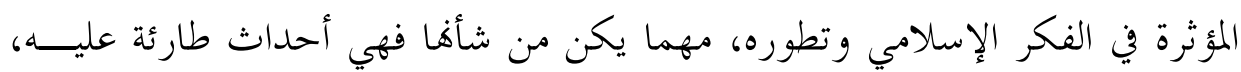

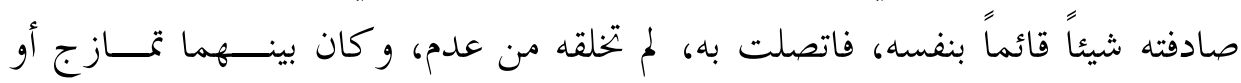

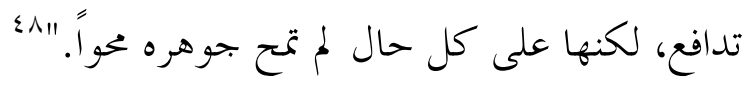

r. حاول دي بور الإعلاء من شأن العقل اليوناني وعلوم اليونان، وإعطـــاءهم

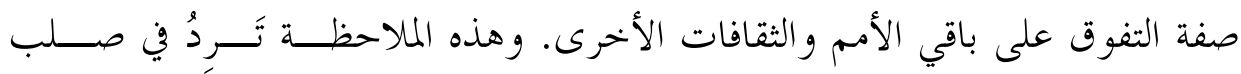

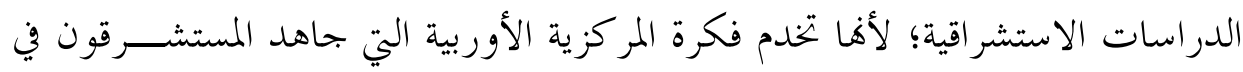
تثبيتها، و الدفاع عنها، و التباهي بها. 
وقد تركزت هذه الملاحظة في كتاب دي بور مرات عديدة، وتواترت في غختلف

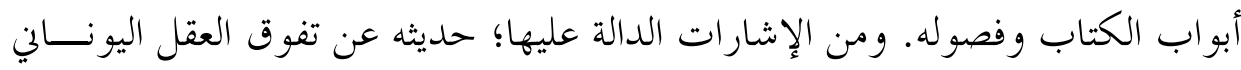

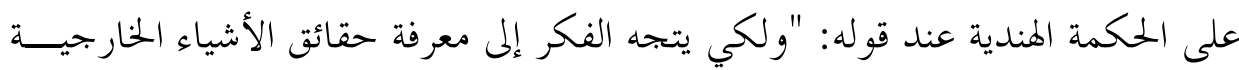

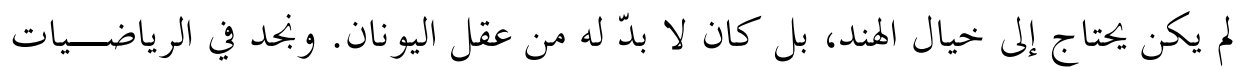

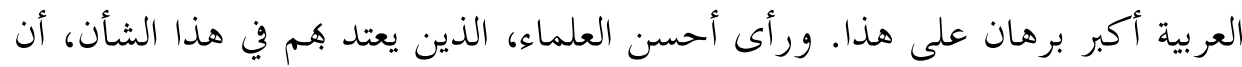

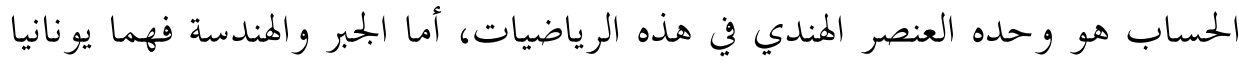

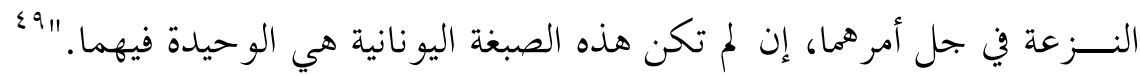

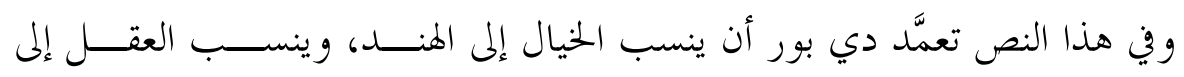

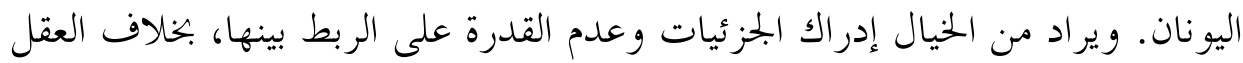
الذي ينهض .بمثل هذه المهمة التركيبية والمنطقية.

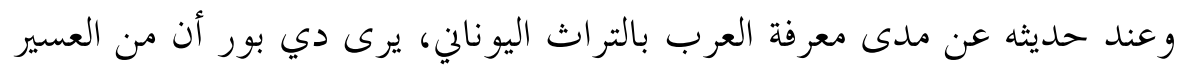

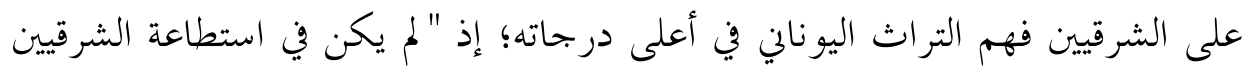

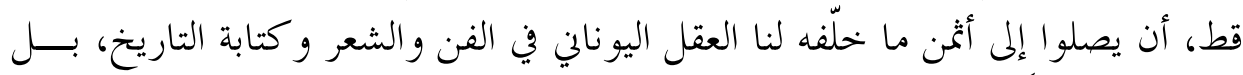

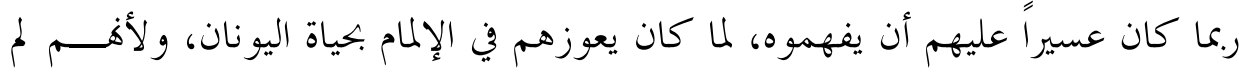
يكونو امتهيئين لتذوق هذه ان الحياة." ل•

r. نفي صفة الابتكار عن الفلاسفة المسلمين، وقد تكررت هذه الملاحظة مـــراراً

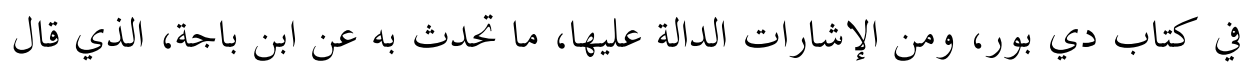

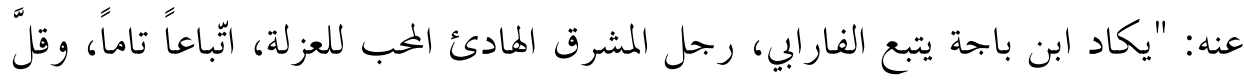

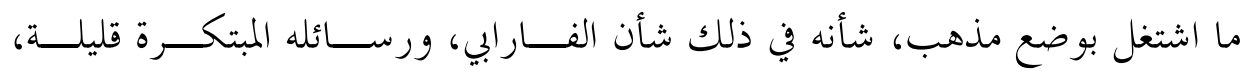

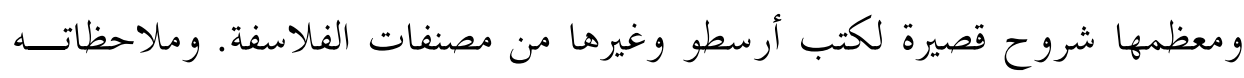

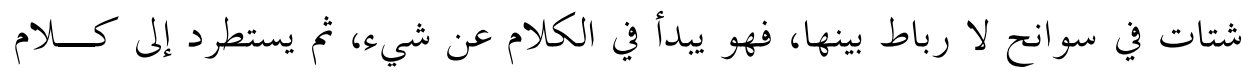

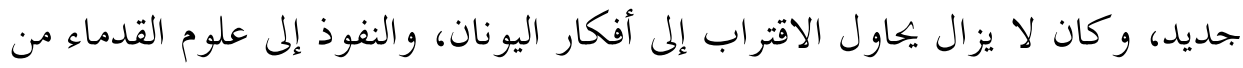

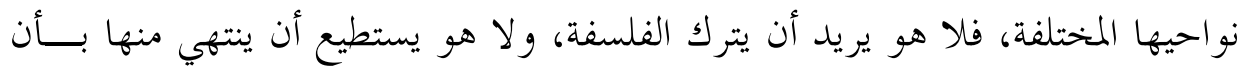

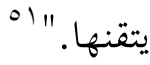

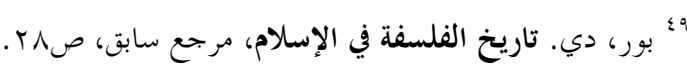

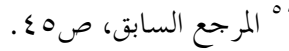

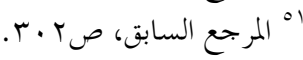


ووصف ابن طفيل بقوله: "وقد زعم أنه يستطيع إصلاح مـــهب بطليمـــــ،

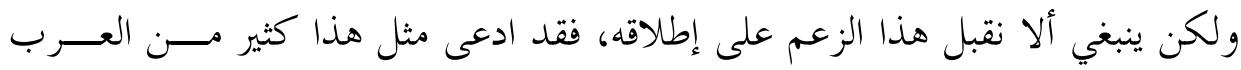

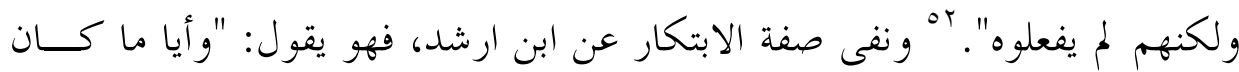
فابن رشد مفكر جريء، منطقي لا اضطراب في تفكيره، وإن لم يكن مفكراً مبتكراً،

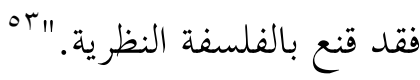

ع. إعطاء التفكير الإسلامي صفة إدراك الجزئيات دون القدرة على ربطها بطريقة

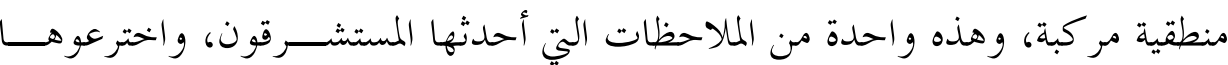
لأنفسهم، وظلوا يتحدثون عنها في كتاباهم، حتى عدت من السِّمات البارزة لخطاهم

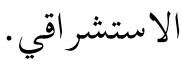

وتكررت إشارة دي بور إلى هذه المسألة مرات عدة، فمرةً عند حديثه عن العرب

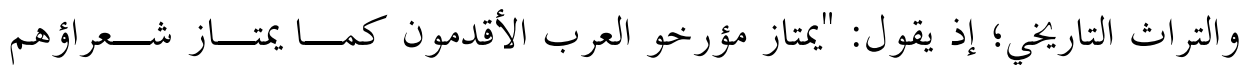

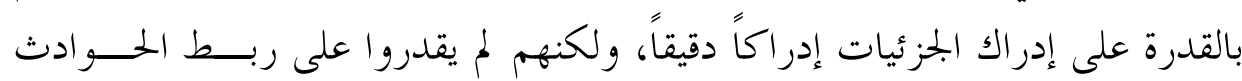

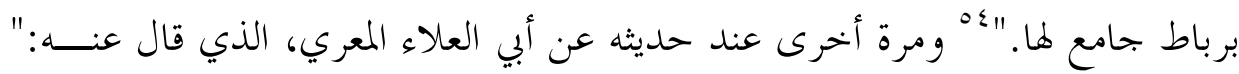

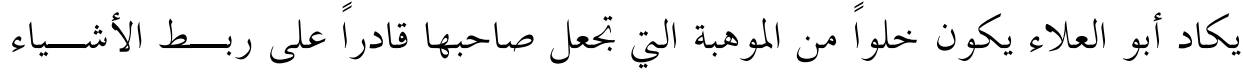

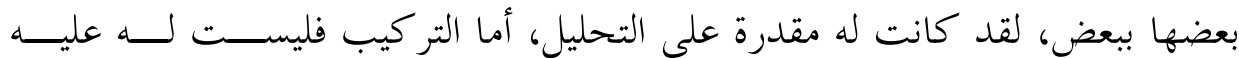

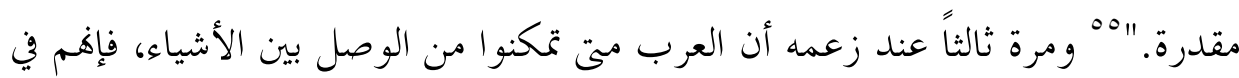

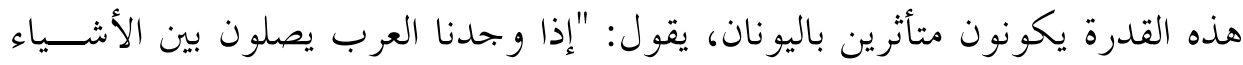

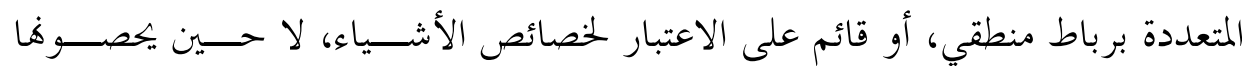

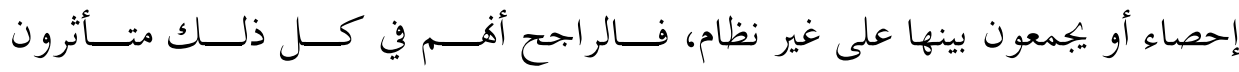
باليونان.

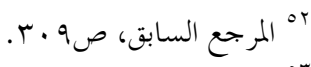

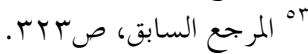

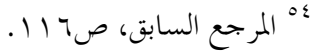

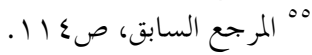

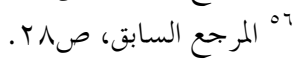


و وي هذا إظهارٌ للتفكير الإسلامي .مظهر الضعف والتشتت و الضآلة في العقلانيــة و المنطقية.

وكنت قد تحدثت عن هذه النــزعة التجزيئية شرحاً ونقداً في كتابي (الإســلام

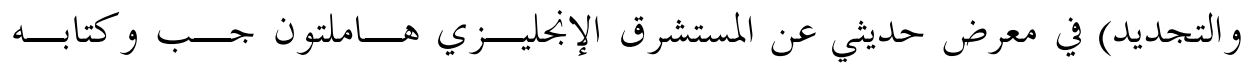

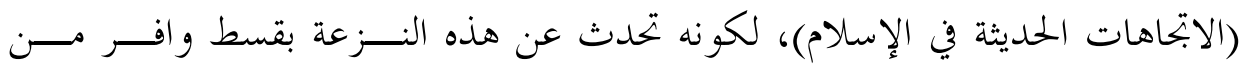
الإفر اط و المبالغة. ه. تحدث دي بور عن ابن خلدون، وتطرق إلى العديد من الجوانب والأبعـاد

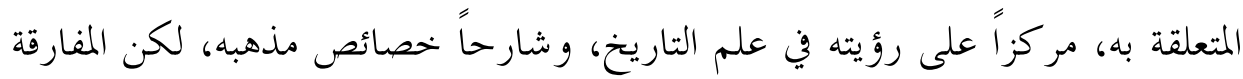

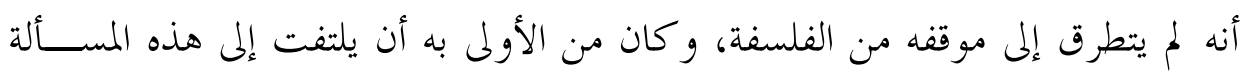

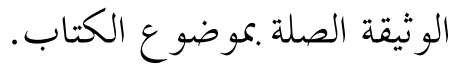

وقد التفت إلى هذه الملاحظة أبو ريدة، وأشار إليها في هامش الكتــاب، وقـــــم تفنيداً لها يمكن العودة إليه. 7. التأكيد على أن المسلمين أخذوا الفلسفة اليونانيــة عــن طريــق المـــهـب الأفلاطولي الجديد، حتى إنّ دي بور قد تحدث عن الفلاسفة المسلمين في إطار ما أسماه

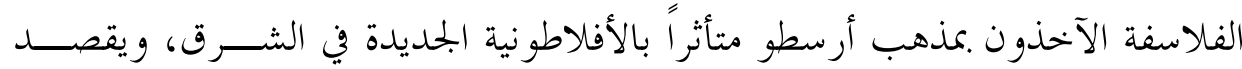
هؤلاء الفلاسفة الكندي و الفار ابي وابن مسكويه وابن سينا وابن الهيثم. ويراد من هذه الملاحظة أن المسلمين فهموا الفلسفة اليونانيــة بطريقـــة ناقصـــة

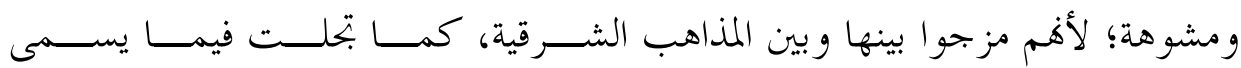

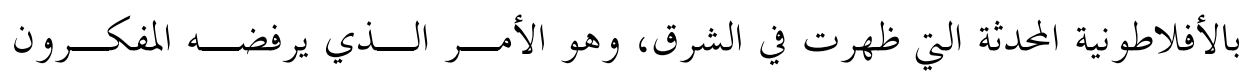

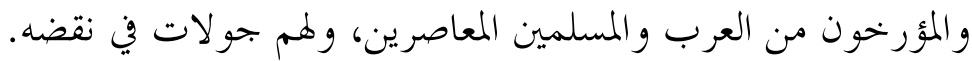

هذه بعض الملاحظات النقدية، التي تجعلنا نعتقد أن كتاب دي بور جاء في سياق الدراسات الاستشراقية، وفي صلب الخطاب الاستشر اقي الأوروبي. 